\title{
Feeding ecology of pelagic decapods in the North Pacific Subtropical gyre: implications for active carbon transport
}

\section{Питание пелагических креветок субтропического круговорота северной части Тихого океана: последствия для активного транспорта органики}

\author{
Yasha Podeswa, Evgeny A. Pakhomov \\ Я. Подешва, Е.А. Пахомов
}

Department of Earth, Ocean and Atmospheric Sciences, University of British Columbia, 2020-2207 Main Mall, Vancouver, BC, V6T1Z4, Canada

* corresponding author: epakhomov@eos.ubc.ca

KEY WORDS: Pelagic shrimps, feeding, North Pacific subtropical gyre, Sergestidae, Caridea, backscattering layers, mesopelagic food webs.

КЛЮЧЕВЫЕ СЛОВА: Пелагические креветки, питание, Северо-тихоокеанский субтропический круговорот, Sergestidae, Caridea, звуко-рассеивающие слои, мезопелагические пищевые сети.

ABSTRACT. Pelagic decapods were collected during October 6-12, 2004 off the southwest coast of Oahu Island, Hawaii. Samples were collected using various micronekton sampling gears in the shallow backscattering layer (SSL, 0-120 m) at night and deep backscattering layer (DSL, 500-700 m) during both day- and nighttime. Three different gears were used, allowing a wide range of macrozooplankton and micronekton to be sampled: a $3 \mathrm{~m}^{2}$ (mouth opening) IsaacsKidd Midwater Trawl with a $5 \mathrm{~mm}$ mesh size, a $4 \mathrm{~m}^{2}$ Hokkaido University Frame Trawl with a $3 \mathrm{~mm}$ mesh size, and a $140 \mathrm{~m}^{2}$ pelagic Cobb trawl with a mesh size narrowing to $10 \mathrm{~mm}$ at the cod end. A total of 30 decapod taxa were identified. Amongst the 22 species with sufficient representation, three migration groups were identified: full migrators (27\% of all species), partial migrators $(59 \%)$, and non-migrators $(14 \%)$. It was found that decapod diet varied not only with size, but also with taxonomic affinity. Diets of nine migrating decapod species mainly included small pelagic crustaceans: calanoid copepods, euphausiids, decapods, ostracods and amphipods, as well as fish, radiolarians, chaetognaths and pelagic mollusks. Generally, there was no significant overlap ( $<30 \%$ of diet similarity) in the diet composition between various species. However, on three occasions the dietary overlap exceeded $50 \%$ (up to a $\max 71 \%$ ) in three species pairs: Notostomus elegans and Oplophorus spinosus due fish consumption; Sergia gardineri and S. scintillans due to consumption of calanoid copepods, particularly Pleuromamma spp., and radiolarians; and finally Neosergestes orientalis and Stylopandalus richardi due to preying upon crustaceans in general with the large copepod contribution. All decapods fed more in the SSL at night than in the DSL during the day or night. However, feeding in the DSL was equal to $9.7-44.7 \%$ of feeding in the SSL by weight. A significant, on average $\sim 20 \%$, decapod feeding occurring at the daytime depth in tropical gyres needs to be taken into account in currently emerging biochemical models aiming to quantify active downward carbon flux via migrating large plankton. The question further arises whether such a pattern holds true for decapods in other regions of the world ocean and for other migratory species of macroplankton and micronekton community which urgently requires further studies.

РЕЗЮМЕ. Пелагические креветки были собраны в октябре 2004 г. в Тихом океане у юго-западного побережья острова Оаху, Гавайи. Для сбора макропланктона и микронектона в поверхностном звукорассеивающем слое (ПЗС, 0-120 м) в ночное время и глубоководном звукорассеивающем слое (ГЗС, 500-700 м) в дневное и ночное время использованы различные орудия лова: трал Айзекса-Кидда, сеть Университета Хоккайдо и пелагический трал Кобба. В уловах обнаружено 30 видов пелагических креветок. Среди 22 репрезентативно обловленных видов 27\% были активными мигрантами, 59\% - частичными мигрантами и $14 \%$ видов не мигрировали. Было установлено, что состав пищи Decapoda значительно варьировал. Девять мигрирующих видов креветок питались в основном мелкими пелагическими ракообразными: веслоногими рачками, эвфаузиидами, декаподами, остракодами и амфиподами, а также рыбой, радиоляриями, хетогнатами и пелагическими моллюсками. Как правило, сходство в составе потреблённой пищи между различными видами не превышало $30 \%$. Однако в трех случаях сходство пищи превысило 50\% (до 
71\%): между Notostomus elegans и Oplophorus spinosus за счет потребления рыбы; между Sergia gardineri и $S$. scintillans из-за потребления веслоногих рачков, в частности Pleuromamma spp., и радиолярий; и наконец, между Neosergestes orientalis и Stylopandalus richardi из-за питания ракообразными в целом, но с большой долей веслоногих рачков. Все креветки питались более интенсивно ночью в ПЗС по сравнению с питанием в течение дня или ночи в ГЗС. Однако весовые индексы наполнения желудков в ГЗС составляли $9,7-44,7 \%$ от таковых в ПЗС. Эту значительную, в среднем 20\%, долю потребления пищи на глубине в течение дня в тропических круговоротах необходимо принимать во внимание в биохимических моделях Мирового океана для более точной оценки активного потока углерода за счет суточных миграций крупного планктона. В настоящее время неизвестно насколько точно оценены пропорции поверхностного и глубинного питания для мигрирующих видов макропланктона и микронектона в других районах Мирового океана, и это настоятельно требует дальнейших исследований.

\section{Introduction}

Macroplankton and micronekton are of particular ecological importance in the mesopelagic zone, where they are one of the most conspicuous members of the community and are also significant components of the epipelagic zone after their nocturnal accent for feeding [Longhurst et al., 1990; Longhurst, 1991; Brodeur, Yamamura, 2005]. These groups are a primary food source for a wide variety of nektonic species that are commercially harvested, such as tuna, swordfish and sharks, and abyssal/bathypelagic predators that migrate up into the mesopelagic depth [Hunt et al., 2000; Kaeriyama et al., 2004; Davison et al., 2013]. Therefore, macroplankton and micronekton are a key link in the food chain between mesozooplankton and the higher trophic levels linking surface and deep waters [Brodeur, Yamamura, 2005].

Pelagic decapods are an abundant and important component of the micronekton community throughout many regions of the world's oceans [Maynard et al., 1975; Hopkins et al., 1989; Flock, Hopkins, 1992]. In the waters near Hawaii, the central North Pacific Subtropical Gyre (NPSG), previous studies have shown dendrobranchiate (penaeids and sergestids) and caridean shrimp to be the first and the fourth most abundant micronekton groups respectively in deep $(0-1200 \mathrm{~m})$ and shallow night time $(0-400 \mathrm{~m})$ tows [Maynard et al., 1975]. Despite the high local abundance and functional importance, limited information is available about the diet or trophic role of pelagic decapods. While several feeding ecology studies have been carried out for pelagic decapod assemblages in the Atlantic and Indian oceans [Foxton, 1970a, b; Foxton, Roe, 1974; Donaldson, 1975; Fasham, Foxton, 1979; Roe, 1984, Flock, Hopkins, 1992; Pakhomov et al., 1992; Hop- kins et al., 1994; Hopkins, Sutton, 1998], to date only one community scale study addressing the feeding ecology of pelagic decapods using presence/absence indices in the NPSG has been completed and it covered only sergestid shrimps [Walters, 1976]. As the NPSG is the largest ecosystem on the planet, and a region being heavily studied by the Hawaii Ocean Time-series (HOT) program [Karl, 1999], it is important to gain further insight into the feeding ecology of local pelagic decapods.

Not only is the diet of pelagic decapods in the central NPSG poorly understood, but the effects of their feeding coupled with diel migratory behavior has not yet been studied. Diel migrants feed primarily in the epipelagic, yet reside in both the epipelagic and mesopelagic layers. Consequently, they transfer carbon to their mesopelagic resident depths through a process known as the active carbon flux [Longhurst et al., 1990]. Active flux attributed to migrant zooplankton in various areas of the world's oceans could be significant compared to local gravitational (passive settling) fluxes [Longhurst, Williams, 1992; Dam et al., 1995; Le Borgne, Rodier, 1997; Steinberg et al., 2000, 2002; Al-Mutairi, Landry, 2001, Hidaka et al., 2001; Davison et al., 2013].

Active carbon flux occurs when organisms consume food primarily or entirely at shallow nocturnal depths, but die, respire, excrete and defecate at all depths [Longhurst, 1991]. If the food fueling these fluxes is consumed only near the surface, there would be a net downward transport of carbon [Longhurst, 1991], but if feeding was occurring equally at all depths, there would be no net carbon transport. Previous estimates of the active carbon flux were made under assumption that the decapods were feeding exclusively in shallow depths at night, with no feeding occurring in the deeper daytime depths. Should this assumption prove incorrect, current active flux estimates could potentially be overestimates [Bianchi et al., 2013; Davison et al., 2013].

A pronounced nocturnal feeding, with full stomachs in organisms caught near the surface at night, but little or no food in the stomachs of organisms caught at depth, has been observed for a range of plankton and micronekton species [references below]. The study on the diurnal feeding behaviour of four euphausiid species in the central NPSG found that two strong vertical migrators (Thysanopoda aequalis and T. monacantha) showed some feeding activity during the day, while a moderate migrator (T. pectinata) appeared to be continuously feeding throughout all depths and times $[\mathrm{Hu}$, 1978]. In a study on the feeding behaviour of ten sergestid shrimp species near Bermuda, stomachs were either equally full during the day and night or visibly not empty during the daytime, implying a continuous feeding over a 24-hour cycle [Donaldson, 1975]. Roe [1984] calculated that daytime feeding of the shrimp Systelaspis debilis could account on average $27 \%$ for the nighttime feeding. Clearly the extent to which pelagic crustaceans and other micronekton groups feed diurnally 
depends strongly on the species being studied but it appears to be common and poorly quantified [e.g. Holton, 1969; Roe, 1984; Roe, Badcock, 1984].

Most previous attempts to study diurnal feeding have focused on changes in the mean stomach mass throughout the day [Donaldson, 1975; Hu, 1978; Hayward, 1980; Longhurst et al., 1989; Stuart, Pillar, 1990]. While this analysis can reveal the presence of nocturnal feeding, it has difficulty differentiating between exclusive nocturnal feeding and feeding occurring at all depths and times. This study examined diurnal changes in prey composition as well as stomach mass in an attempt to more accurately quantify the feeding occurring at both shallow night time and deep daytime depths. The aims were threefold: (a) describe the prey composition of the most abundant pelagic decapod species; (b) quantify the distribution of feeding efforts across time and depth; and (c) determine whether organism size or taxonomy plays a larger role in the diet specialization.

\section{Materials and Methods}

Samples were collected in October 6-12, 2004 on board the NOAA research ship Oscar Elton Sette during the Micronekton Intercalibration Experiment in the Pacific Ocean [Pakhomov, Yamamura, 2010] (Fig. 1, also see sampling tracks in the insert). A total of 56 midwater trawl hauls were conducted off the southwest coast of Oahu Island, Hawaii over bottom depths ranging between 700 and $1200 \mathrm{~m}$. Sampling was carried out both at night (from 8:00 pm to 5:00 am local time) and during the day (from 8:00 am to 5:00 pm), sampling both the surface backscattering layer (SSL, $\sim 0-120 \mathrm{~m}$ ) and the deep backscattering layer (DSL, 500-700 m). Three different gears were used, allowing a wide range of macrozooplankton and micronekton to be sampled. These included: a $3 \mathrm{~m}^{2}$ Isaacs-Kidd Midwater Trawl (IKMT) with a $5 \mathrm{~mm}$ mesh size, a $4 \mathrm{~m}^{2}$ Hokkaido University Frame Trawl (HUFT) with a $3 \mathrm{~mm}$ mesh size, and a $140 \mathrm{~m}^{2}$ pelagic Cobb trawl with a mesh size narrowing to $10 \mathrm{~mm}$ near the cod end. The number of samples collected with each gear in each depth range is shown in Table 1. Trawls were not conducted during the day in the SSL, due to the virtual absence of micronekton in this layer during daytime. Samples were sorted into major taxonomic groups (decapods, euphausiids, tunicates, fish, amphipods, copepods, stomatopods, etc.), and certain taxonomic groups (such as fish and squid) were removed from the samples and preserved separately for use in a separate study. All decapods, as well as all macrozooplankton and mesozooplankton, were preserved in a 4-6\% formalin seawater solution for further analysis in the laboratory.

In the lab, all decapods in the preserved samples were identified to the species level. Of the 30 species caught, only 9 were included in the dietary analyses (Table 2). Of the species excluded most were simply rare, some were too small to perform a meaningful
Table 1. Number of trawls conducted at each depth, at each time of day during October 6-12, 2004 off the southwest coast of Oahu, Hawaii. SSL - shallow backscattering layer, DSL - deep backscattering layer. IKMT - Isaacs-

Kidd Midwater Trawl, HUFT - Hokkaido University Frame Trawl, Cobb - pelagic Cobb trawl.

Таблица 1. Количество тралений, выполненных на той или иной глубине в определенное время у юго-западного побережья о. Оаху (Гавайские острова) с 6 по 12 октября 2004 г. SSL - верхний звукорассеивающий слой, DSL - нижний звукорассеивающий слой. IKMT разноглубинный трал Айзекса-Кидда, HUFT рамочный трал Университета Хоккайдо, Cobb пелагический трал Кобба.

\begin{tabular}{|l|c|c|c|}
\hline Gear & SSL, nighttime & DSL, nighttime & DSL, daytime \\
\hline IKMT & 1 & 1 & 6 \\
\hline HUFT & 13 & 1 & 6 \\
\hline Cobb & 8 & 3 & 6 \\
\hline
\end{tabular}

quantitative gut content analysis using a dissecting microscope (e.g. Lucifer typus and Neosergestes consobrinus), while remaining were only sampled at one depth or time and were not found at other depths and times of day making impossible to analyze their diel feeding patterns. For the species included in the analysis, up to 75 individuals per species were analyzed, with 15 individuals from each of 5 different depth-time intervals. These included: (1) individuals caught in the SSL during the early night, from 8:00 pm - 12:30 am (Shallow EN), (2) individuals caught in the SSL during the late night, from 12:30 am - 5:00 am (Shallow LN), (3) individuals caught in the DSL during the early day, from 8:00 am - 12:30 pm (Deep ED), (4) individuals caught in the DSL during the late day, from 12:30 am5:00 pm (Deep LD), and (5) individuals caught in the DSL at any point during the night, from 8:00 pm - 5:00 am (Deep E/LN).

Once decapods were identified to the species level, their total lengths as well as mass were measured (to 1 $\mathrm{mg}$ ). Total length was measured from the posterior margin of the telson to the posterior edge of the orbit using calipers with a precision of $0.1 \mathrm{~mm}$. Stomachs were removed and their fullness (as a percentage of fullness) was estimated visually. Stomachs were then opened, the food bolus was removed and its wet mass was measured. Prey composition was determined through visual analysis of the food bolus under a dissecting microscope.

Pelagic decapods use mandibular teeth to masticate their prey into small pieces, so whole prey are rarely found in their stomachs. However, the gears with the finer mesh nets (IKMT and HUFT) caught potential prey items, which were identified to the species level when possible, dissected, and body parts of the taxonomic importance photographed to facilitate prey identification to the lowest possible taxon. For example, the molar process of the mandibles of euphausiids and decapods tend to be species/genus specific and appeared to be well preserved in stomachs even when the softer body parts have been largely digested. Once the prey items within an individual stomach were identi- 


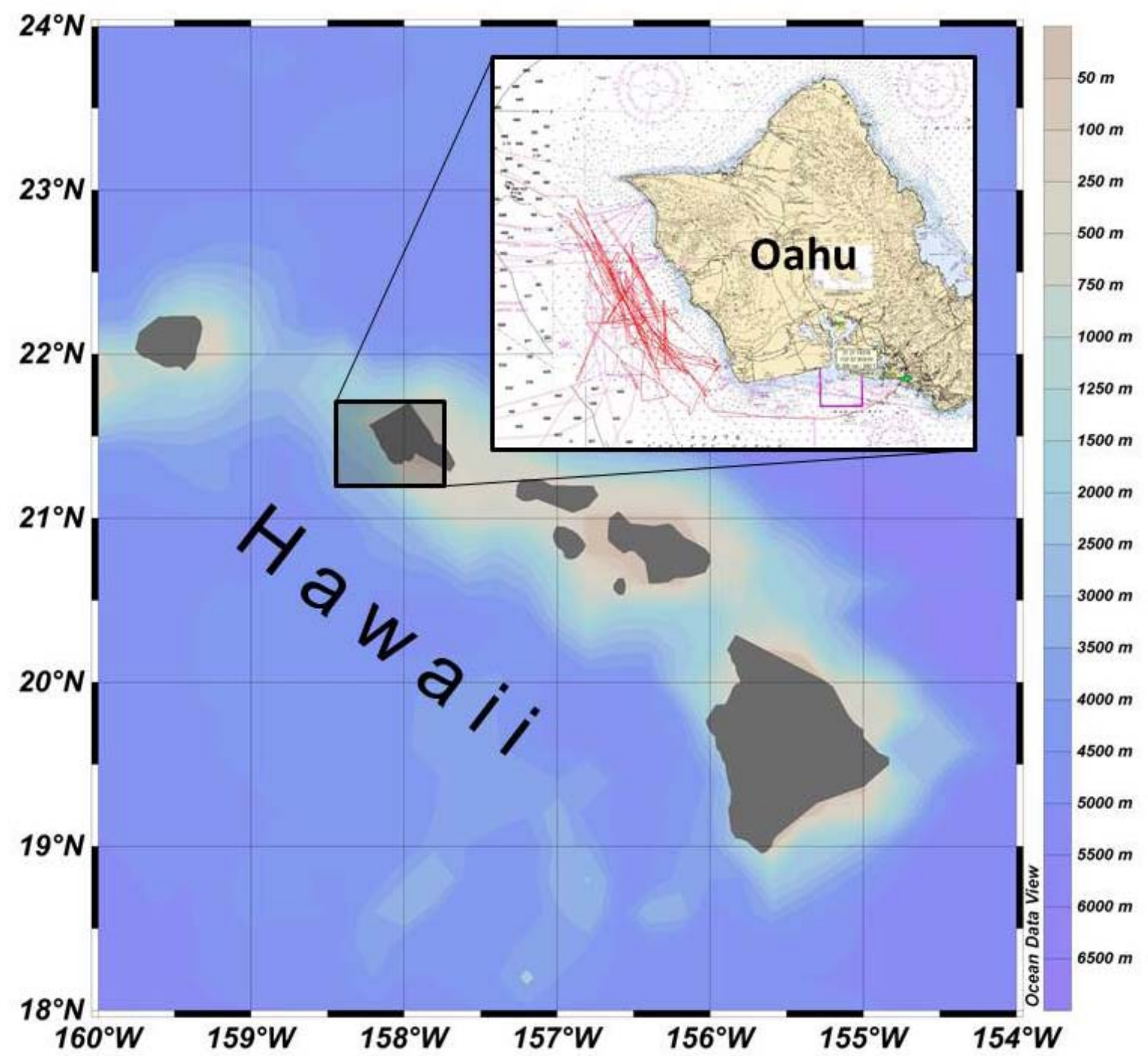

Fig. 1. Map of the sampling area: insert shows actual tow tracks of trawls (Table 1) carried out off the southwest coast of Oahu Island, Hawaii during October 6-12, 2004.

Рис. 1. Район сбора проб: вставка показывает фактические маршруты тралений (Таблица 1) выполненных у юго-западного побережья острова Оаху, Гавайские острова с 6 по 12 октября 2004 г.

fied to the lowest taxonomic level possible, the visual percentage contribution of each prey item to the overall food bolus volume, with a precision of $5 \%$, was estimated. In addition, the digestion stage of each prey item was assessed according to the following scale: (1) whole animal, virtually undigested; (2) body mostly in one piece, appendages detached, some digestion of soft parts visible; (3): soft parts mostly digested, entire animal fragmented; (4): only hard parts identifiable, soft parts largely digested; (5): a highly digested, unidentifiable remains are found in the stomach. The food bolus and the decapod were then oven-dried at $50{ }^{\circ} \mathrm{C}$ for 24-72 hours and their dry mass determined using a scale with a resolution of $0.01 \mathrm{mg}$.

To assess changes in the stomach fullness through different depth/time intervals, the Stomach Fullness Index (SFI) proposed by Hureau [1969], SFI (\%) =
$100 * F B D W / O r g D W$, was used, where $F B D W$ is the food bolus dry mass in $\mathrm{mg}$ and $\operatorname{Org} D W$ is the organism's dry mass (mg). The SFI (as ratio only) was also calculated for each decapod, and the mean SFIs at each depth/time interval were compared using an ANOVA, with a $\mathrm{p}$-value lower than 0.05 indicating a statistically significant difference in SFI at one of more depth/time intervals.

Prey composition for each decapod species was calculated in terms of the mean dry mass $(\mu \mathrm{g})$ of each prey item found in the stomachs. Mean prey dry mass was calculated by multiplying the $F B D W$ by the percentage contribution of this prey item to the overall food bolus volume. This assumed that all prey items have the same density, which might not be the case. This was however the best compromise since it was impossible to accurately measure the dry mass of indi- 
Table 2. Pelagic decapod species composition and species used for diet analyses caught during October 6-12, 2004 off the southwest coast of Oahu, Hawaii.

Таблица 2. Видовой состав пелагических видов Decapoda и виды, использованные для анализа состава пищи в ходе траловых работ у юго-западного побережья о. Оаху (Гавайские ос птрова) с 6 по 12 октября 2004 г.

\begin{tabular}{|c|c|c|c|}
\hline Species & Family & Diet analysed & Number of stomachs \\
\hline Gennadas bouvieri Kemp,1909 & Benthesicymidae & No & 0 \\
\hline Gennadas tinayrei Bouvier, 1906 & Benthesicymidae & No & 0 \\
\hline Lucifer typus H. Milne Edwards, 1837 & Luciferidae & No & 0 \\
\hline Nematocarcinus sp. & Nematocarcinidae & No & 0 \\
\hline Acanthephyra smithi Kemp, 1909 & Oplophoridae & Yes & 41 \\
\hline Acanthephyra quadrispinosa Kemp, 1939 & Oplophoridae & No & 0 \\
\hline Janicella spinicauda (A. Milne-Edwards, 1883) & Oplophoridae & Yes & 75 \\
\hline Notostomus elegans A. Milne-Edwards, 1881 & Oplophoridae & Yes & 13 \\
\hline Oplophorus gracilirostris A. Milne-Edwards, 1881 & Oplophoridae & Yes & 75 \\
\hline Systellaspis debilis (A. Milne-Edwards, 1881) & Oplophoridae & No & 0 \\
\hline Stylopandalus richardi (Coutiére, 1905) & Pandalidae & Yes & 75 \\
\hline Heterocarpus parvispina De Man, 1917 & Pandalidae & No & 0 \\
\hline Eupasiphae gilesii Wood-Mason, 1892 & Pasiphaeidae & No & 0 \\
\hline Pasiphaea affinis Rathbun, 1902 & Pasiphaeidae & No & 0 \\
\hline Funchalia taaningi Burkenroad, 1940 & Penaeidae & No & 0 \\
\hline Allosergestes pectinatus (Sund, 1920) & Sergestidae & No & 0 \\
\hline Allosergestes sargassi (Ortmann, 1893) & Sergestidae & No & 0 \\
\hline Deosergestes erectus (Burkenroad, 1940) & Sergestidae & No & 0 \\
\hline Neosergestes consobrinus (Milne, 1968) & Sergestidae & No & 0 \\
\hline Neosergestes orientalis (Hansen, 1919) & Sergestidae & Yes & 75 \\
\hline Parasergestes armatus (Krøyer, 1855) & Sergestidae & Yes & 49 \\
\hline Parasergestes vigilax (Stimpson, 1860) & Sergestidae & No & 0 \\
\hline Sergestes atlanticus $\mathrm{H}$. Milne Edwards, 1830 & Sergestidae & No & 0 \\
\hline Sergia bigemmea (Burkenroad, 1940) & Sergestidae & No & 0 \\
\hline Sergia bisulcata (Wood-Mason et Alcock, 1891) & Sergestidae & No & 0 \\
\hline Sergia gardineri $($ Kemp, 1919) & Sergestidae & Yes & 75 \\
\hline Sergia inequalis (Burkenroad, 1940) & Sergestidae & No & 0 \\
\hline Sergia scintillans (Burkenroad, 1940) & Sergestidae & Yes & 46 \\
\hline Sergia tenuiremis (Krøyer, 1855) & Sergestidae & No & 0 \\
\hline Thalassocaris lucida (Dana, 1852) & Thalassocarididae & No & 0 \\
\hline
\end{tabular}

vidual prey items. For each decapod species the mean prey composition in specimens caught in both the SSL and DSL was calculated, to allow for a comparison between stomach contents during the day and night.

For six pelagic decapod species, two methods were used to estimate the percentage of feeding occurring at depth, one method representing a reasonable upper boundary for this estimate, with the other method representing its reasonable lower boundary. Upper and lower boundaries for the estimate of feeding at depth were computed separately for each decapod species. The upper boundary was established using the equation:

Upper boundary $(U B)=\left(S F I_{D S L} / S F I_{S S L}\right) * 100 \%$, where $S F I_{D S L}$ is the mean SFI in the deep scattering layer, and $S F I_{S S L}$ is the mean SFI in the shallow scattering layer. The UB represents an upper boundary for the estimate of feeding at depth because it assumes that $100 \%$ of food bolus of decapods caught in the DSL is due to feeding at depth, as opposed to food consumed in the SSL that has yet to be fully digested. The lower boundary for the percentage of feeding occurring at depth was established using the equation:

Lower boundary $(L B)=\left(\right.$ Prey $D W_{D L S}$ Prey $\left.D W_{S S L}\right) * 100 \%$, where Prey $D W_{D S L}$ is the dry mass of all prey taxa occurring exclusively or "nearly exclusively" in decapod stomachs collected in the DSL, and Prey $D W_{S S L}$ is the dry mass of all prey taxa occurring in decapod stomachs from the SSL, including both prey taxa found exclusively in the SSL, and prey taxa found in both the SSL and DSL. "Nearly exclusively" found in the DSL was defined as prey taxa for which DSL dry mass was at least 5 times of SSL dry mass. The equation representing a lower boundary for the feeding activity estimate at depth assumes that, for prey taxa found in considerable quantities during both the SSL and DSL, the prey dry mass in the DSL collected stomachs is due exclusively to partially digested SSL feeding and not at all due to DSL feeding.

In addition to the species specific analyses, the stomach content data were analyzed using the PRIMER software package (Plymouth Routines in Multivariate Ecological Research, version 6.1.12). A hierarchical agglomerative method was used between and within species comparison and a Bray-Curtis Similarity Index was used to quantify similarity [Clarke, Warwick, 2001]. Prey composition data, expressed as dry mass, were $\log$ transformed $(\log (\mathrm{x}+1))$ to reduce bias 


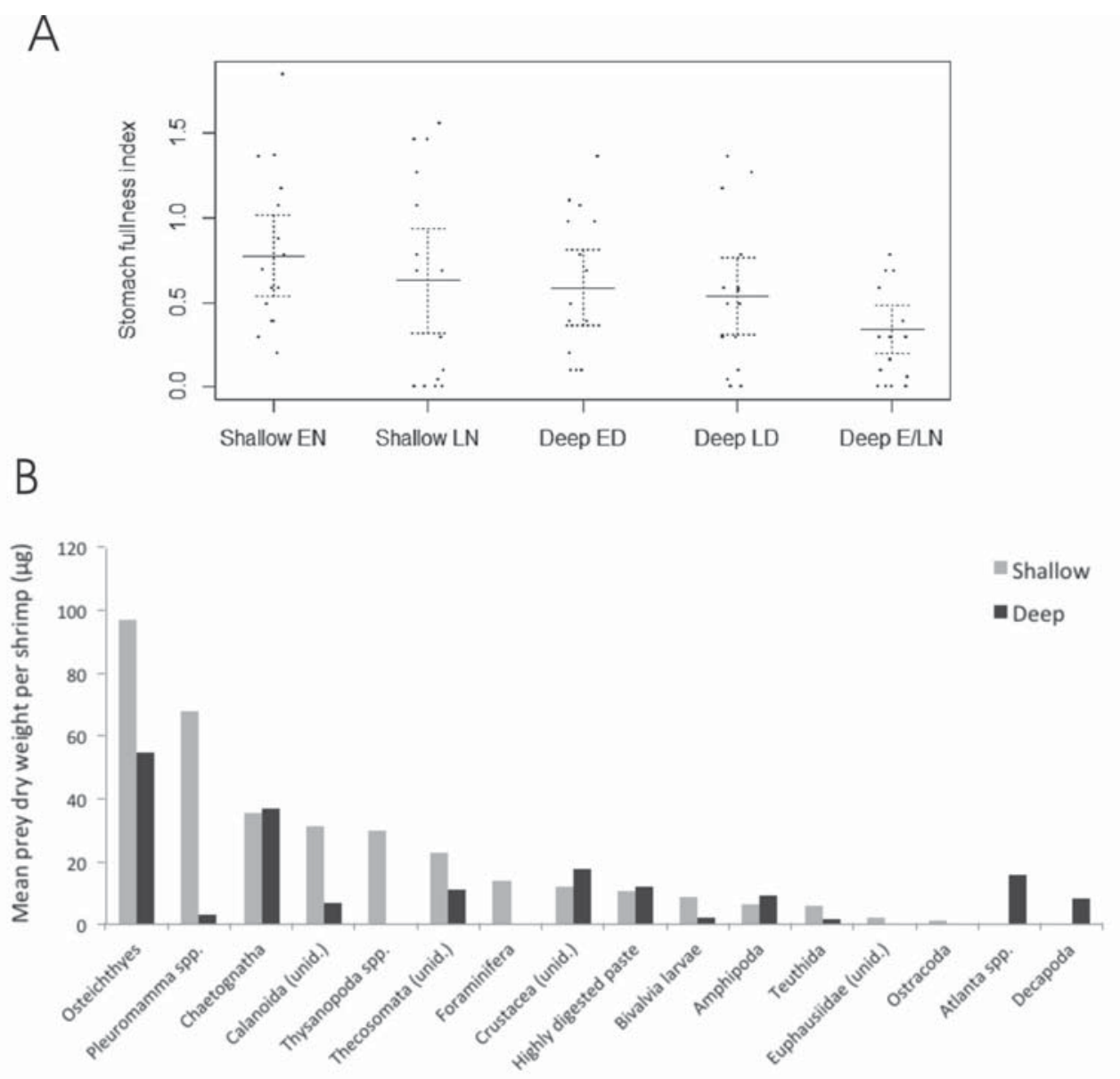

Fig. 2. Janicella spinicauda stomach fullness index (A) and diet composition (B) through its diel vertical migrations. Error bars show $95 \%$ confidence intervals for the estimate of the mean.

Рис. 2. Индексы наполнение желудка (А) и состав пищи (Б) во время суточных вертикальных миграций у креветок Janicella spinicauda. Вертикальные линии отражают 95\% доверительные интервалы средней оценки.

due to highly abundant prey [Clarke, Warwick, 2001]. First, prey composition was averaged for all decapods by the depth/time interval at which decapods were collected: Shallow EN, Shallow LN, Deep ED, Deep LD and Deep E/LN, with each interval representing one "site." Second, prey composition was averaged by the decapod species. Third, prey composition was averaged based on the individual decapod mass (not species specific) into bins of the natural logarithm of their dry mass (bins were $\ln (\mathrm{DW})(\mathrm{mg})=1-2,2-3,3-4$, etc.). For example, " $1-2$ " bin represented the prey composition of all decapods with a $\ln (\mathrm{DW})$ of $1-2 \mathrm{mg}$, e.g. DW of 2.72-7.39 mg; "2-3" bin represented the prey composition of all decapods with a $\ln (\mathrm{DW})$ of 2 $3 \mathrm{mg}$ (DW of 7.39-20.09 mg), and so on.

Following the cluster analysis, an analysis of similarities (ANOSIM) was performed. ANOSIM is a nonparametric, multivariate analysis similar to analysis of variance (ANOVA). Instead of testing for a difference between a set of group means, ANOSIM tests for differences in relative similarities in community composition, in this case using a Bray-Curtis Similar- ity matrix [Clarke, Warwick, 2001]). The analysis was performed for the same three routines used in the cluster analysis: depth/time interval, decapod species, and decapod mass. For each factor, a test statistic, R, was calculated [Clarke, Warwick, 2001]. The value of $\mathrm{R}$ lies between -1 and +1 , with a value of 1 indicating that all replicates within a group are more similar to one another than to replicates from other groups, a value of 0 indicating that there is no difference between groups, and a value of -1 indicating that all replicates within groups are less similar to one another than to replicates from other groups [Clarke, Warwick, 2001]. A total of 999 random permutations were conducted to assess the significance level of $\mathrm{R}$, with a significance level of 0.05 or lower being considered statistically significant [Clarke, Warwick, 2001].

To compare the diets of all species investigated, a food similarity index (FSI) was calculated using the formula: $F S I=\sin r(i, j)$, where $\min r(i, j)$ is a minimal contribution (\%) by mass of food item $r$ in the two species $i$ and $j$ [Shorygin, 1952]. 
A
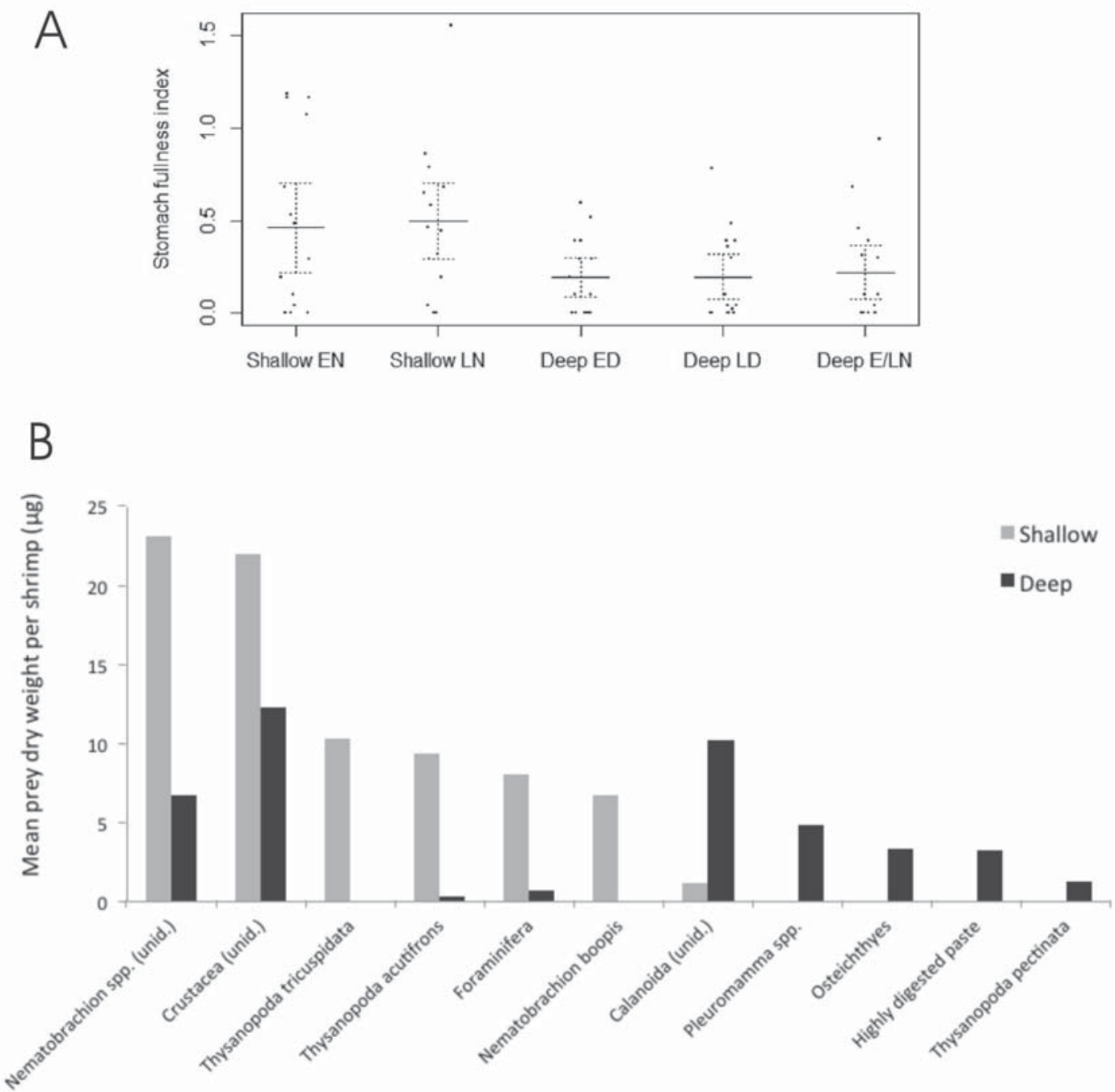

Fig. 3. Neosergestes orientalis stomach fullness index (A) and diet composition (B) through its diel vertical migrations. Error bars show $95 \%$ confidence intervals for the estimate of the mean.

Рис. 3. Индексы наполнение желудка (А) и состав пищи (Б) во время суточных вертикальных миграций у креветок Neosergestes orientalis. Вертикальные линии отражают 95\% доверительные интервалы средней оценки.

\section{Results}

For six of the 9 species (Janicella spinicauda, Neosergestes orientalis, Oplophorus gracilirostris, Sergia gardineri, S. scintillans and Stylopandalus richardi) up to 75 individuals per species were analyzed, at all depth/time intervals (Table 2). For two of the species (Acanthephyra smithi and Parasergestes armatus), no individuals were caught in either of the shallow intervals (Shallow EN or Shallow LN), likely because they did not migrate up to $120 \mathrm{~m}$, so only individuals from the Deep ED, Deep LD and Deep E/LN were analyzed. Notostomus elegans were caught only in the Deep E/LN interval, but were included in the analysis because of their exceptionally large size, and thus significant contribution to local decapod biomass (Table 2).

Janicella spinicauda (total length range 15-36 mm, mean length $28.2 \mathrm{~mm}$, mean dry mass $40.1 \mathrm{mg}$ ) showed a trend of decreasing SFIs throughout the day, with SFIs peaking in the Shallow EN interval, and progressively lowering at each interval through to Deep E/LN (Fig. 2A). However, SFIs did not vary significantly between depth/time intervals $(\mathrm{p}=0.0519, \mathrm{~F}=2.4767$, $\mathrm{DF}=4$ and 70 ). It should be noted that the $\mathrm{p}$-value was very close to the 0.05 significance level cut off, so it is possible that the sample size was simply not large enough to detect a statistically significant difference in mean SFIs. Sixteen different prey taxa were found in $J$. spinicauda stomachs, with osteichthyes (fish) and calanoid copepod Pleuromamma spp. being the largest contributors to mean prey dry mass (Fig. 2B). For most prey, its mean DW was higher for shrimp caught in the SSL than for shrimp caught in the DSL. Two prey taxa were found only in the stomachs of shrimp caught in the DSL: heteropod Atlanta spp. and unidentified Decapoda (Fig. 2B). 


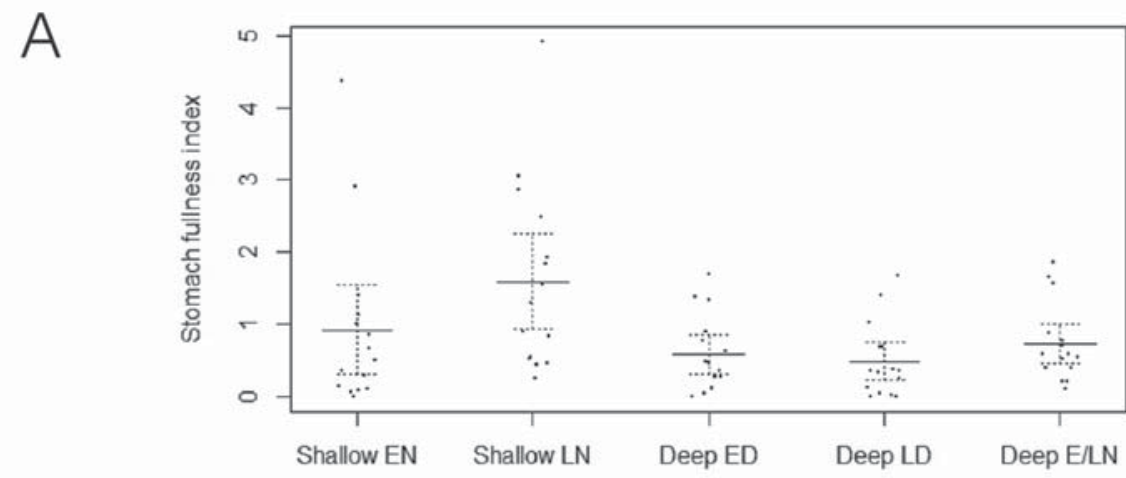

B

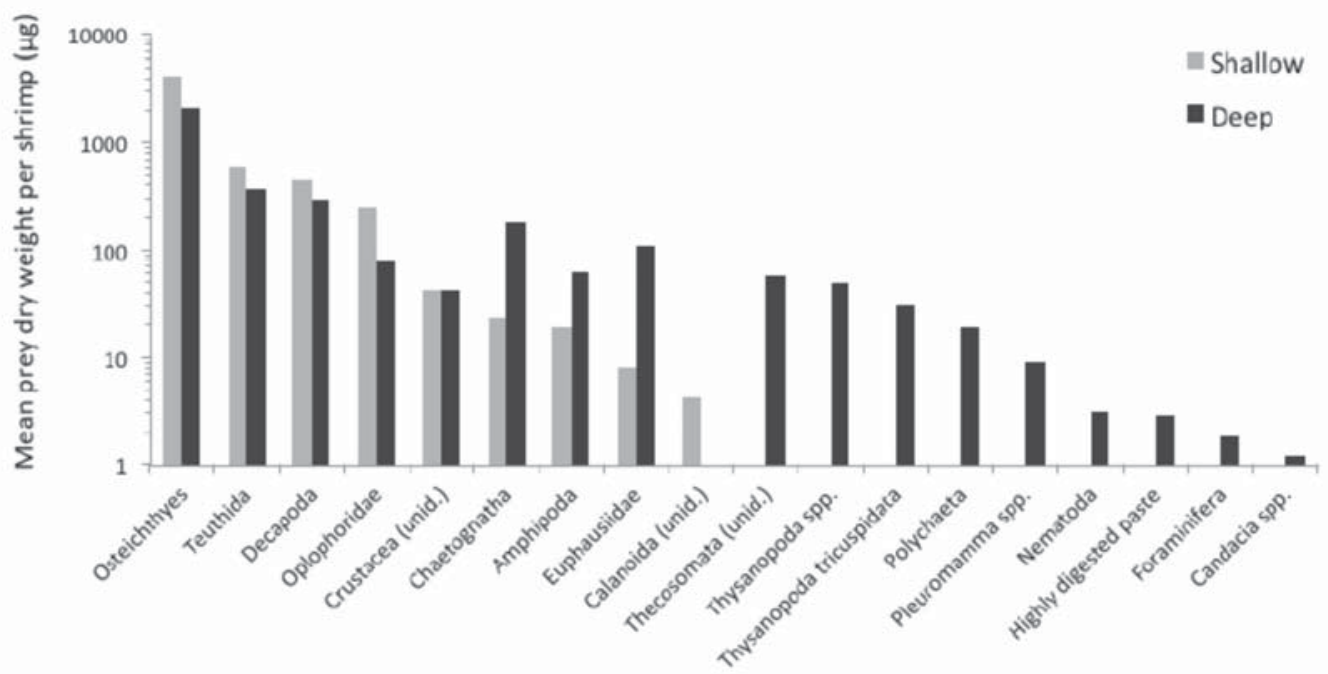

Fig. 4. Oplophorus gracilirostris stomach fullness index (A) and diet composition (B) through its diel vertical migrations. Error bars show $95 \%$ confidence intervals for the estimate of the mean. Note that vertical axis is log scale.

Рис. 4. Индексы наполнения желудка (А) и состав пищи (Б) во время суточных вертикальных миграций у креветок Oplophorus gracilirostris. Вертикальные линии отражают 95\% доверительные интервалы средней оценки. Обратите внимание, что на вертикальной оси логарифмическая шкала.

Neosergestes orientalis (total length range 17-32 $\mathrm{mm}$, mean length $26.9 \mathrm{~mm}$, mean dry mass $29.8 \mathrm{mg}$ ) had generally high SFIs near the surface and low SFIs at depth (Fig. 3A). An ANOVA showed that SFIs varied significantly between different depth/time intervals $(\mathrm{p}=0.0228, \mathrm{~F}=3.0369, \mathrm{DF}=4$ and 70$)$. It is worth noting that there appeared to be a slight (but not significant) increase in SFIs from when individuals would have recently migrated to depth (Deep ED) to the time interval when shrimps supposed to be longest at depth (Deep E/LN) (Fig. 3A). Eleven prey taxa were found in $N$. orientalis stomachs, with the euphausiid Nematobrachion spp. and unidentified crustaceans comprising largest proportions of the mean food bolus mass (Fig. 3B). Pleuromamma spp., osteichthyes and the euphausiid Thysanopoda pectinata were exclusively found in stomachs of shrimp caught in the DSL (Fig. 3B). Highly digested food (unidentifiable paste) was found only in shrimp caught in the DSL.
Stomach fullness indices of Oplophorus gracilirostris (total length range 19-61 mm, mean length 48.6 $\mathrm{mm}$, mean dry mass $824.9 \mathrm{mg}$ ) were higher near the surface than at depth with the highest SFIs recorded during the Shallow LN time interval (Fig. 4A). SFIs varied significantly between different depth/time intervals $(\mathrm{p}=0.0101, \mathrm{~F}=3.5936, \mathrm{DF}=4$ and 70$)$. Of the three intervals in the DSL, mean SFI was highest for shrimp caught in the Deep E/LN, when they would be expected to have been at depth for the longest period of time, though none of the deep intervals had mean SFI statistically different from one another (Fig. 4A). Eighteen different prey taxa were identified in the $O$. gracilirostris stomachs, with osteichthyes dominating the mean dry mass of the prey (Fig. 4B). Although all were minor contributors to the overall diet, eight prey taxa were only recorded in shrimp caught in the DSL. In addition three groups; chaetognaths, amphipods and euphausiids, were also mainly found in the diet of DSL 

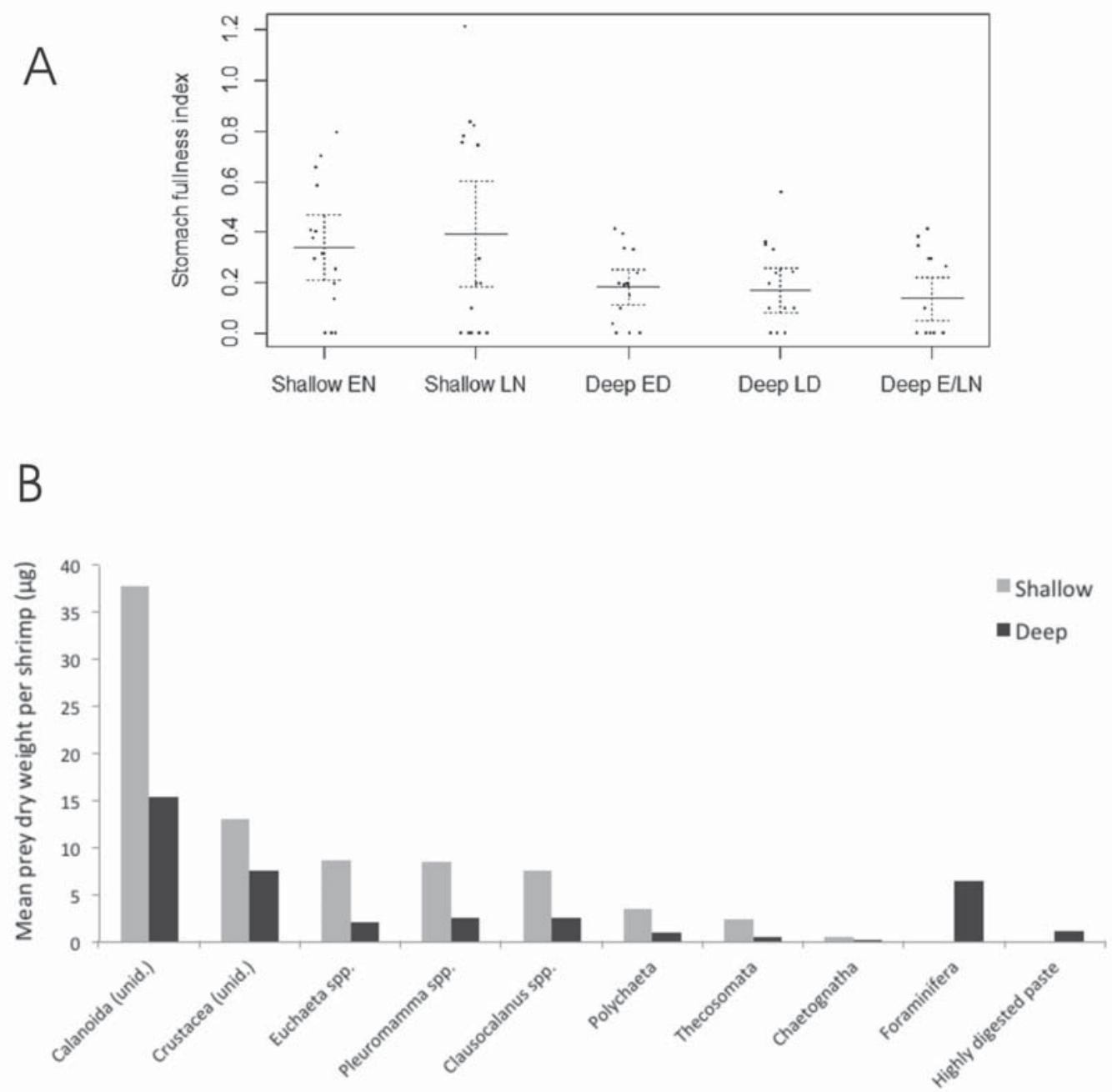

Fig. 5. Sergia gardineri stomach fullness index (A) and diet composition (B) through its diel vertical migrations. Error bars show $95 \%$ confidence intervals for the estimate of the mean.

Рис. 5. Индексы наполнения желудка (А) и состав пищи (Б) во время суточных вертикальных миграций у креветок Sergia gardineri. Вертикальные линии отражают 95\% доверительные интервалы средней оценки.

shrimp (Fig. 4B). This was accompanied by a small contribution of the highly digested prey (Fig. 4B).

Sergia gardineri (total length range $21-33 \mathrm{~mm}$, mean length $26.5 \mathrm{~mm}$, mean dry mass $35.6 \mathrm{mg}$ ) had generally high SFIs near the surface, and generally low SFIs at depth, with mean SFI peaking during the Shallow LN interval (Fig. 5A). An ANOVA showed that SFIs varied significantly between different depth/ time intervals $(\mathrm{p}=0.0210, \mathrm{~F}=3.0943, \mathrm{DF}=4$ and 70). Ten different prey taxa were found in $S$. gardineri stomachs, with unidentified calanoid copepods being the largest contributors to mean prey dry mass (Fig. 5B). Foraminiferans were found only in shrimp caught in the DSL, as was the highly digested food (Fig. 5B).

Sergia scintillans (total length range $27-37 \mathrm{~mm}$, mean length $32.4 \mathrm{~mm}$, mean dry mass $45.6 \mathrm{mg}$ ) had generally high and low SFIs near the surface and depth, respectively, with the mean SFIs peaking during the Shallow
EN interval (Fig. 6A). The SFIs varied significantly between different depth/time intervals $(p=0.0175, F=$ 3.3879 , DF $=4$ and 70). In the DSL, mean SFI was the highest in the Deep LD interval, although no intervals in the DSL were statistically different from one another (Fig. 6A). Only eight prey taxa were found in S. scintillans stomachs, with unidentified calanoid copepods being the largest contributors to the mean prey mass (Fig. 6B). Osteichthyes and Pleuromamma spp. were found only in shrimp caught in the DSL (Fig. 6B).

Stylopandalus richardi (total length range $20-36 \mathrm{~mm}$, mean length $29.1 \mathrm{~mm}$, mean dry mass $65.8 \mathrm{mg}$ ) had low mean SFIs at all depth/time intervals except highest SFIs in the Shallow LN (Fig. 7A). Indeed, an ANOVA confirmed that SFIs varied significantly between different depth/time intervals $(\mathrm{p}<0.0001, \mathrm{~F}=20.2770, \mathrm{DF}=4$ and 70). Thirteen different prey taxa were found in $S$. richardi stomachs. Crustaceans were the main prey of $S$. richardi (Fig. 7B). Among them, euphausiid Thysanop- 


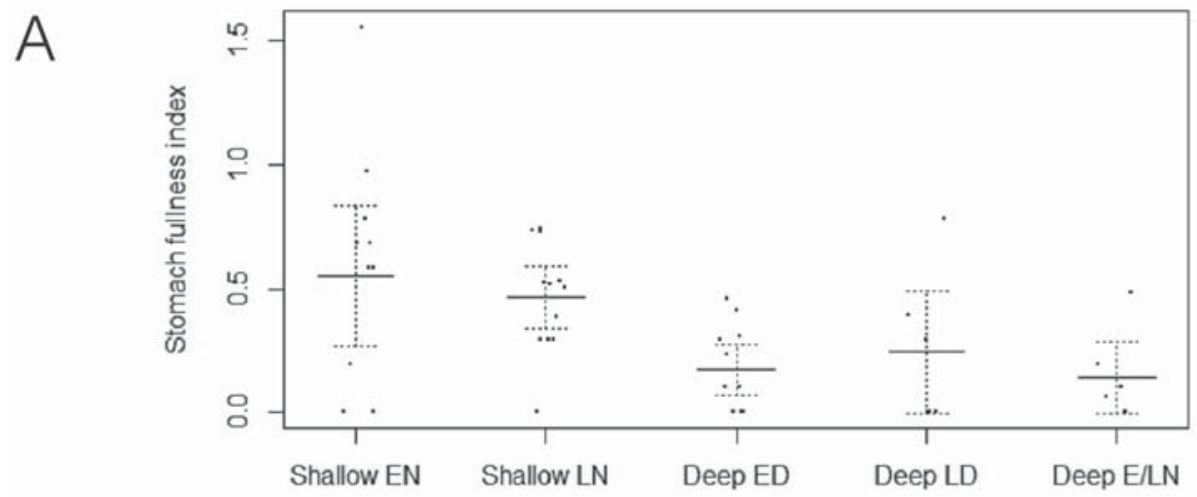

B

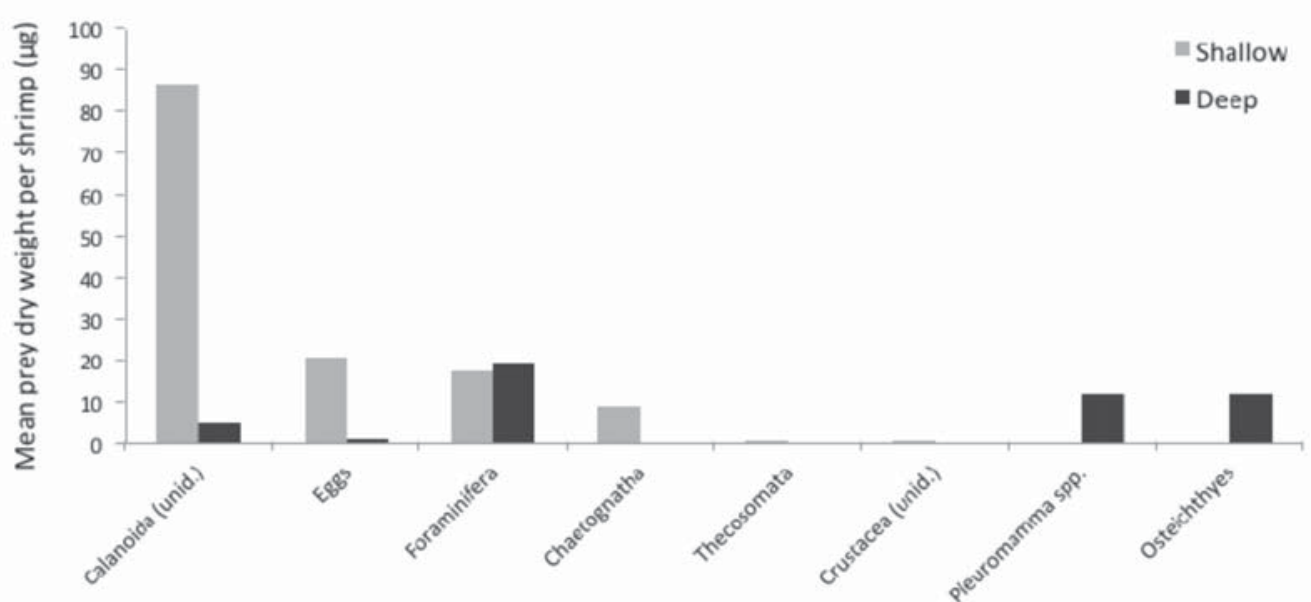

Fig. 6. Sergia scintillans stomach fullness index (A) and diet composition (B) through its diel vertical migrations. Error bars show $95 \%$ confidence intervals for the estimate of the mean.

Рис. 6. Индексы наполнения желудка (А) и состав пищи (Б) во время суточных вертикальных миграций у креветок Sergia scintillans. Вертикальные линии отражают 95\% доверительные интервалы средней оценки.

oda acutifrons and crustacean eggs were only found in shrimp stomachs caught in the DSL (Fig. 7B).

The following three decapod species, namely Acanthephyra smithi, Parasergestes armatus, and Notostomus elegans, were only collected in the DSL time intervals, likely because they did not migrate into the SSL during the night. A. smithi was found during the Deep ED, Deep LD, and Deep E/LN intervals, with very little difference in mean SFIs throughout these time intervals (Fig. 8A). An ANOVA failed to identify differences in mean SFIs for all intervals $(p=0.8891$, $\mathrm{F}=0.1179, \mathrm{DF}=2$ and 38). Fourteen prey taxa were recorded in A. smithi (total length range $35-83 \mathrm{~mm}$, mean length $60.4 \mathrm{~mm}$, mean dry mass $626.3 \mathrm{mg}$ ) stomachs (Fig. 8B). Decapods of the family Pandalidae comprised main prey group by dry mass, although unidentified crustaceans, decapods of the family Ophlophoridae, osteichthyes and polychaetes also accounted for large proportions of the shrimp diet (Fig. 8B).

Parasergestes armatus (total length range 29-44 $\mathrm{mm}$, mean length $38.7 \mathrm{~mm}$, mean dry mass $67.8 \mathrm{mg}$ ) was found during the Deep ED, Deep LD, and Deep E/ $\mathrm{LN}$ intervals, also with very little difference $(\mathrm{p}=0.7852$, $\mathrm{F}=0.2432, \mathrm{DF}=2$ and 42) in mean SFIs through these intervals (Fig. 9A). Nine different prey taxa were found in $P$. armatus stomachs, with calanoid copepods accounting for the largest proportion of the diet, while euphausiids and decapods ranked second and third in the importance (Fig. 9B).

Notostomus elegans (total length range 37-113 mm, mean length $74.4 \mathrm{~mm}$, mean dry mass $1746 \mathrm{mg}$ ) were very rare in the samples, with a total of only 13 specimens collected. Their diet was however analyzed regardless as they were significant contributors to local decapod biomass due to their very large size. The mean individual dry mass of $N$. elegans was one to two order of magnitude larger that most other decapod species mean dry mass varied between 10 and $100 \mathrm{mg}$. $N$. elegans were found only in the DSL at night (Fig. $10 \mathrm{~A})$, and their mean SFIs were not statistically significant in individuals caught during the Deep EN and the Deep LN ( $p=0.9068, F=0.0144, D F=1$ and 11). 


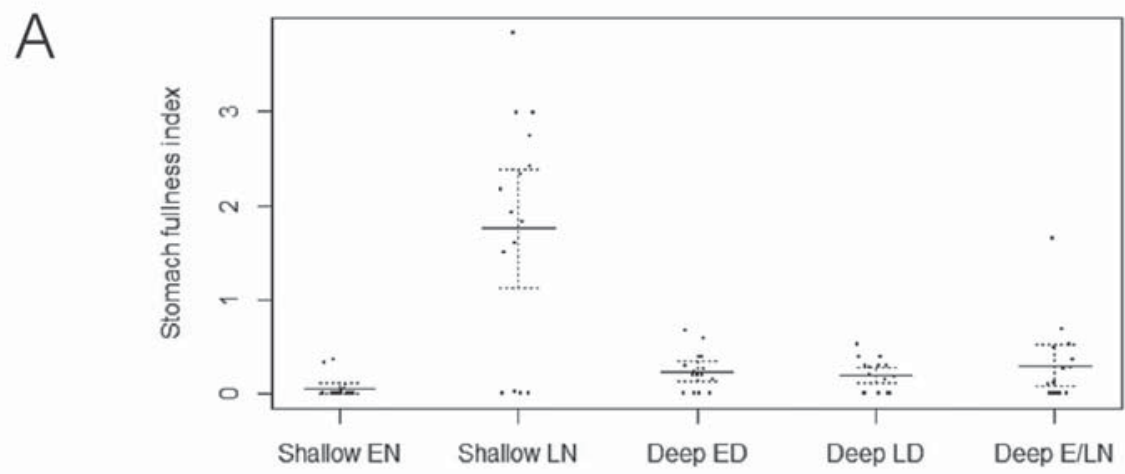

B

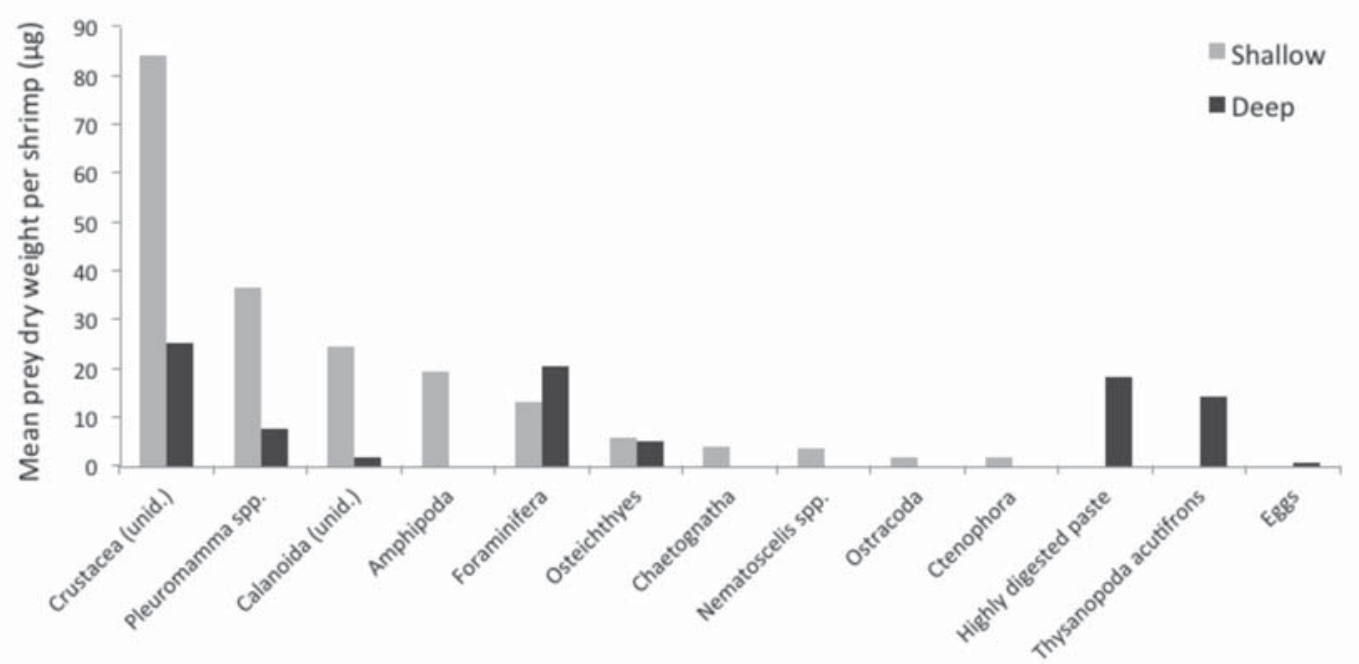

Fig. 7. Stylopandalus richardi stomach fullness index (A) and diet composition (B) through its diel vertical migrations. Error bars show $95 \%$ confidence intervals for the estimate of the mean.

Рис. 7. Индексы наполнения желудка (А) и состав пищи (Б) во время суточных вертикальных миграций у креветок Stylopandalus richardi. Вертикальные линии отражают 95\% доверительные интервалы средней оценки.

Only 3 prey taxa were found in $N$. elegans stomachs, with osteichthyes being the most prominent prey (Fig. 10B).

Averaged for six species, the upper and lower boundaries of feeding estimates at depth expressed as a percentage of feeding during the day in DSL were $44.7 \%$ and $9.7 \%$ of prey consumption near the surface, respectively (Table 4). The geometric mean of all values was $18.5 \%$ (Table 4.). The "highly digested food" was not included in the above calculations as it is likely (but may be not entirely) a result of a digestion of prey consumed in the SSL at night.

Cluster analysis showed that overall SSL and DSL decapod (not species specific) diets appeared to be different (Fig. 11A). However, two main clusters were separated at a Bray-Curtis Similarity of $66.5 \%$ (Fig. 11A). Indeed, an ANOSIM run on the full data set, with depth/time intervals as the factor failed to find significant differences in prey composition between the different intervals $(\mathrm{p}=0.106, \mathrm{R}=0.003)$.
Two main species groups at the $\sim 19 \%$ level of similarity were identified using the cluster analysis (Fig. 11B). One group contained only four oplophorid species, which were with one exception all large species with the mean individual mass ranging between 626 and $1746 \mathrm{mg}$, while the other group contained small sized decapods (mean mass 10-100 mg) including four sergestid and a pandalid species (Fig. 11B). Diets expressed as dry mass per individual were quite dissimilar between two main groups although at the similarity level of $50 \%$, three smaller clusters were visible (Fig. 11B). An ANOSIM run on the full data set, however, confirmed that the prey composition was significantly different between species $(\mathrm{p}<$ $0.001, \mathrm{R}=0.161)$. Indeed, food similarity indices (FSI) between all 9 species calculated based on the data presented in Table 3 generally did not exceed $40 \%$ (mean $21 \pm 12 \%$ ) suggesting no significant overlap in the diet composition between various species. Similarly with above analysis, on three occasions the 

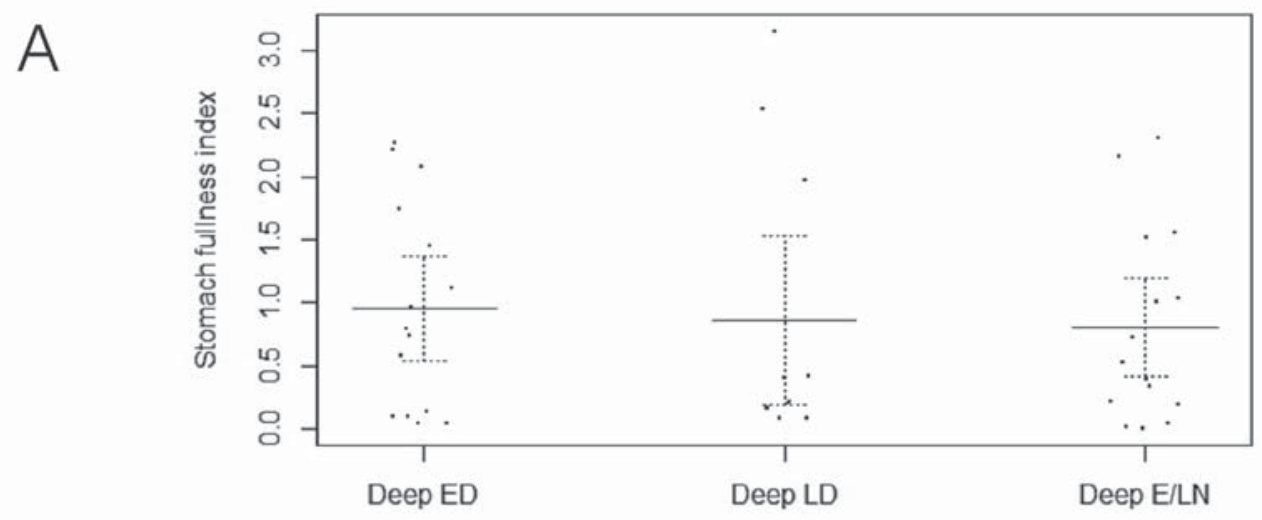

B

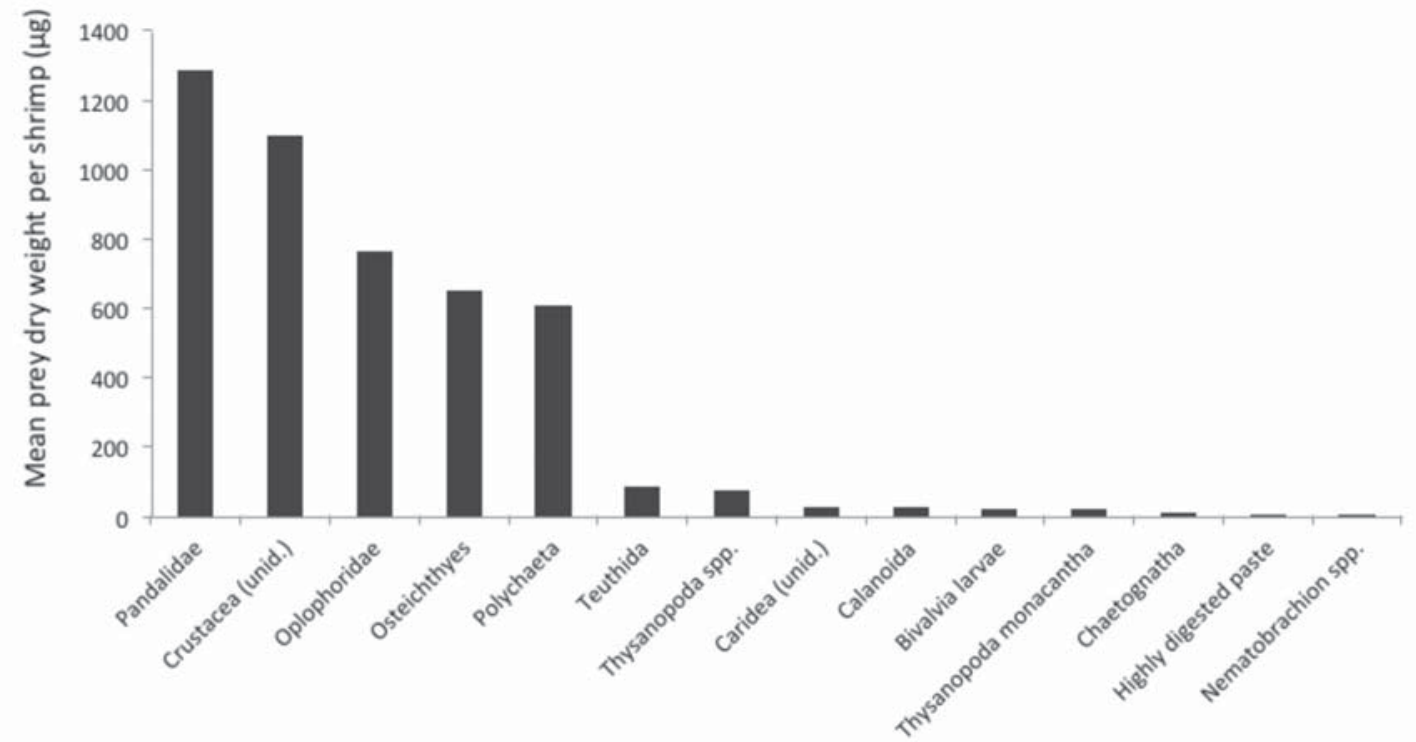

Fig. 8. Acanthephyra smithi stomach fullness index (A) and diet composition (B) through its diel vertical migrations. Error bars show $95 \%$ confidence intervals for the estimate of the mean.

Рис. 8. Индексы наполнения желудка (А) и состав пищи (Б) во время суточных вертикальных миграций у креветок Acanthephyra smithi. Вертикальные линии отражают 95\% доверительные интервалы средней оценки.

dietary overlap was high reaching $71 \%$ between $\mathrm{No}$ tostomus elegans and Oplophorus spinosus due to fish consumption; 61\% between Neosergestes orientalis and Stylopandalus richardi due to preying upon crustaceans in general with the large copepod contribution, and $57 \%$ between Sergia gardineri and $S$. scintillans due to consumption of calanoid copepods, particularly Pleuromamma spp., and radiolarians (Table 3).

Decapod diets averaged by the shrimp size (ln(DW) bins) clearly clustered into two main groups with a further subsequent sub-clustering at higher similarity levels (Fig. 11C). Small and medium sized decapods consumed mostly small crustaceans (copepods and euphausiids), while larger shrimps were mainly preying upon fish, decapods and large euphausiids (Table 3). An ANOSIM test found highly significant differences in the diet between subsequent size bins of pelagic shrimps $(\mathrm{p}<0.001, \mathrm{R}=0.035)$.

\section{Discussion}

\section{Diurnal feeding}

The stomach fullness data confirmed an intensive nocturnal feeding in the subsurface layers for all migrating decapod species investigated. While it seems that decapods were feeding more in the SSL, the prey composition data separated by depth also strongly suggested the daytime feeding in the DSL. Indeed, between one and eleven prey taxa (excluding highly digested food) occurred exclusively or almost exclusively in decapods caught in the DSL. Furthermore, all prey taxa that appeared to have been consumed in the 

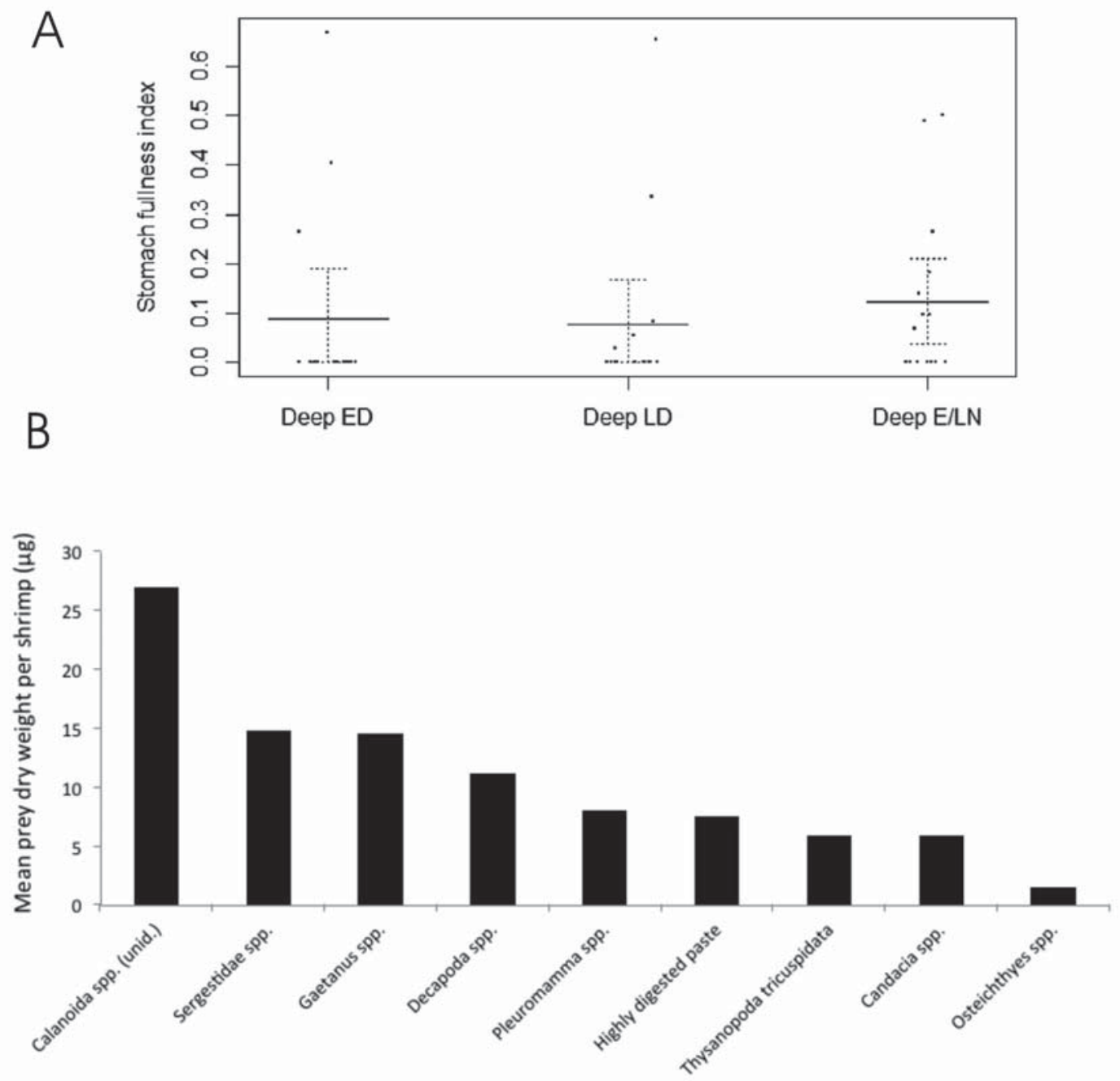

Fig. 9. Parasergestes armatus stomach fullness index (A) and diet composition (B) through its diel vertical migrations. Error bars show $95 \%$ confidence intervals for the estimate of the mean.

Рис. 9. Индексы наполнения желудка (А) и состав пищи (Б) во время суточных вертикальных миграций у креветок Parasergestes armatus. Вертикальные линии отражают 95\% доверительные интервалы средней оценки.

DSL (Atlanta spp., Candacia spp., foraminifera, Pleuromamma spp., Thysanopoda species, chaetognatha, decapoda, euphausiidae, osteichthyes and polychaeta) are known to occur in the mesopelagic layers [e.g. Nemoto, 1968; Maynard et al., 1975; Mauchline, 1985; Steinberg et al., 2008; Hull et al., 2011] and thus it is reasonable to assume that they could have been eaten at depth. The estimated upper boundary meant to be a theoretical maximum estimate of the feeding at depth and may likely represent a significant overestimate. It assumed that all food ingested in the SSL has passed out of the stomach by the time the shrimp were caught in the DSL. While this could be the case for some prey items, or even parts of certain prey items, the harder to digest prey and body parts would not be evacuated this rapidly [Clarke, 1980]. Likewise, the lower boundary makes a nearly opposite assumption that at any time prey found in shrimp stomachs caught in the SSL and DSL, $100 \%$ of it should have been consumed in the
SSL. Thus, any prey present in stomachs of shrimp caught in the DSL should simply be a residual prey from feeding in the SSL. An exception was only made in cases when the mean dry mass of prey in the DSL exceeded that of that in the SSL. In such cases, it was far more likely that prey was consumed in the DSL and not in the SSL. Nevertheless, the lower boundary was meant to be a very conservative estimate and that is almost certainly too low.

One process that could actually cause the lower boundary to be an overestimate of feeding at depth, as opposed to an underestimate, is the diet natural variance. The sample size of 75 stomachs per species (30 from the SSL, 45 from the DSL) may be not large enough to disentangle properly day- and nighttime feeding. This seems unlikely, however, for three reasons. First, prey taxa were often found in at least 3 to $6 \mathrm{DSL}$ stomachs, but not in a single SSL stomach. Second, as in case of $O$. gracilirostris when 11 of 18 prey taxa 


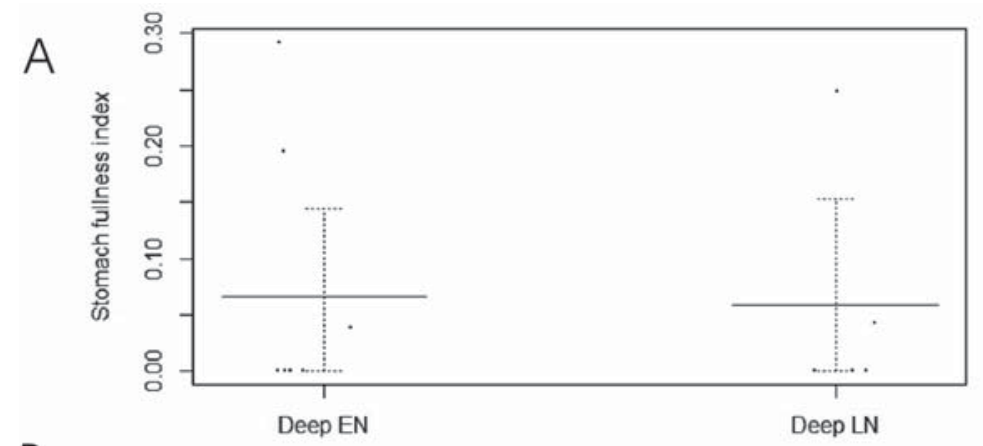

B

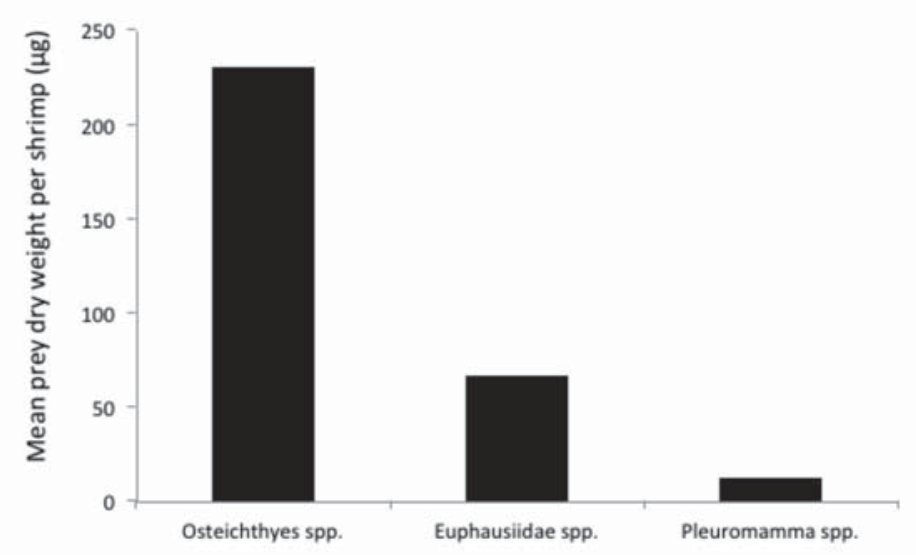

Fig. 10. Notostomus elegans stomach fullness index (A) and diet composition (B) through its diel vertical migrations. Error bars show $95 \%$ confidence intervals for the estimate of the mean.

Рис. 10. Индексы наполнения желудка (А) и состав пищи (Б) во время суточных вертикальных миграций у креветок Notostomus elegans. Вертикальные линии отражают 95\% доверительные интервалы средней оценки.

(excluding highly digested food) were found exclusively in DSL shrimp stomachs. Lastly, the cluster analysis further supported the hypothesis of feeding in the DSL because all three DSL depth/time intervals clustered together, as did the two SSL depth/time intervals. While it suggested differences in prey composition between layers, there was a high level of similarity between DSL and SSL gut contents overall, which is not surprising considering that many prey items consumed in the SSL could still be getting digested in the DSL, and vice versa.

\section{Size versus taxonomic affinity}

This study also attempted to answer a question of what controls pelagic decapod diets: species size and/ or taxonomy. Our findings showed that decapod diets clustered strongly based on both the size and the species composition proving to be the strong determinants of their dietary preferences. At the broadest level, two main decapod groups were either containing only sergestid and pandalid species or only oplophorid species. The sergestid and pandalid group was composed exclusively of relatively small species, while the oplophorid group comprised predominantly of large species with only one species falling into the sergestid/ pandalid group size category. Small Janicella spinicauda clustered strongly with Oplophorus gracilirostris, a species 20 times of former size in terms of mean individual mass. While strongly different in terms of size, both species are highly similar taxonomically and morphologically, to the point that J. spinicauda formerly belonged to the genus Oplophorus [Chace, 1986]. However, if size of the consumed prey is taken into account diets of these species would overlap marginally [Pakhomov et al., 1992]. It thus appears that size alone cannot explain dietary preference of the pelagic decapods with taxonomy likely influencing the diet through similarity in feeding structures between taxonomically related species. ANOSIM analyses further confirmed that shrimp diets were more similar within species groups than within groups organized based solely on the organism mass. This further emphasized that while decapod size clearly plays a key role in diet specialization it can only explain decapod diets in combination with their taxonomic affiliation. It appears that should a given pelagic decapod species be removed from the ecosystem through a targeted fishery or ecosystem change, a similarly sized decapod species may not necessarily be able to fill the same niche.

It should be noted that diets were also highly dissimilar between species, with just a $\sim 20 \%$ similarity in 

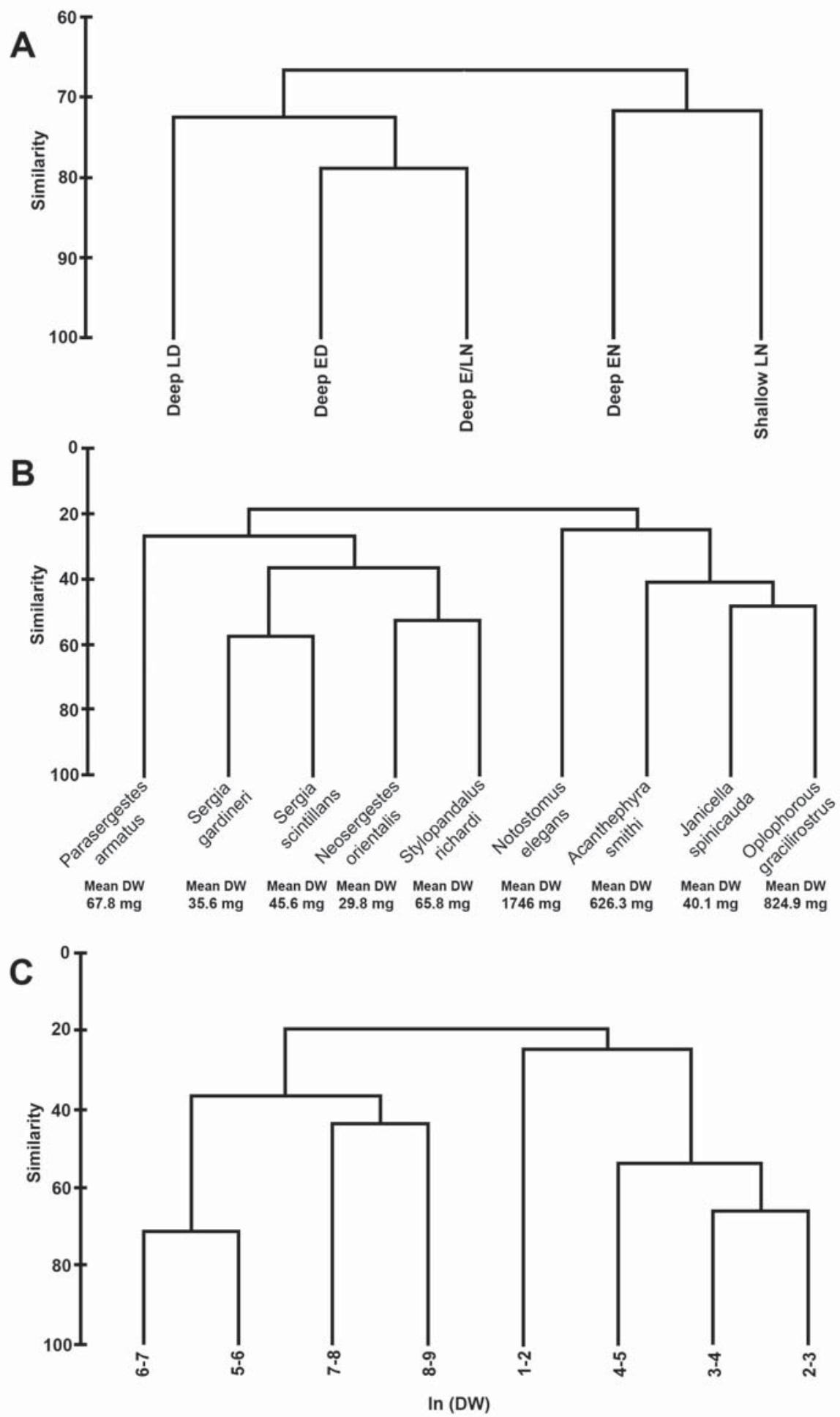

Fig. 11. Bray-Curtis Similarity dendrograms: (A) of the decapod (all species) prey composition collected in 5 different depth/time intervals: in the SSL during the early and late night (Shallow EN and Shallow LN), and in the DSL during the early day, late day, and early/ late night (Deep ED, Deep LD and Deep E/LN); (B) of the prey composition of 9 decapod species analyzed in this study. The mean individual dry mass of each species is also provided; (C) of the prey composition of all species (not species specific) in shrimp mass bins, $\ln (\mathrm{DW})$.

Рис. 11. Дендрограмма построенная на основе индекса сходства Брея-Куртиса: (А) состава пищи креветок (всех виды объединены) в 5 разных интервалов обловленных глубин (Shallow EN and Shallow LN), а также в DSL в начале дня, поздним днем и ночью (Deep ED, Deep LD and Deep E/LN); (B) состава пищи девяти видов проанализированных креветок. Приводится также средняя индивидуальная сухая масса каждого вида; (C) состава пищи креветок (всех виды объединены), сгруппированных согласно эквивалентным логарифмическим интервалам массы $(\ln (\mathrm{DW}))$ креветок. 
Table 3. Prey composition of nine decapod species studied collected during October 6-12, 2004 off the southwest coast of Oahu, Hawaii expressed as \% of total prey dry mass. As — Acanthephyra smithi, Js — Janicella spinicauda, No - Neosergestes orientalis, Ne — Notostomus elegans, Og - Oplophorus gracilirostris, $\mathrm{Pa}$ - Parasergestes armatus, Sg — Sergia gardineri, Ss - Sergia scintillans, Sr Stylopandalus richardi.

Таблица 3. Состав пищи девяти видов десятиногих ракообразных, собранных у юго-западного побережья о. Оаху (Гавайские ос птрова) с 6 по 12 октября 2004 г.

\begin{tabular}{|c|c|c|c|c|c|c|c|c|c|}
\hline \multirow[t]{2}{*}{ Dietary components } & \multicolumn{9}{|c|}{ Decapod species } \\
\hline & As & Js & No & $\mathrm{Ne}$ & $\mathrm{Og}$ & $\mathrm{Pa}$ & $\mathrm{Sg}$ & Ss & $\mathrm{Sr}$ \\
\hline Foraminifera & - & 2.3 & 6.2 & - & $<0.1$ & - & 6.9 & 20.0 & 13.1 \\
\hline Candacia spp. & 0.6 & - & - & - & $<0.1$ & 6.1 & - & - & - \\
\hline Clausocalanus spp. & - & - & - & - & - & - & 8.1 & - & - \\
\hline Euchaeta spp. & - & - & - & - & - & - & 8.3 & - & - \\
\hline Gaetanus spp. & - & - & - & - & - & 15.1 & - & - & - \\
\hline Pleuromamma spp. & - & 11.8 & 5.0 & 3.9 & 0.1 & 8.4 & 8.8 & 6.5 & 14.4 \\
\hline Calanoida unidentified & 0.6 & 6.8 & 11.4 & - & $<0.1$ & 27.9 & 42.9 & 49.9 & 8.1 \\
\hline Amphipoda & - & 3.3 & - & - & 1.1 & - & - & - & 5.8 \\
\hline Nematobrachion boopis & - & - & 4.7 & - & - & - & - & - & - \\
\hline Nematobrachion spp. & 0.1 & - & 22.8 & - & - & - & - & - & - \\
\hline Nematoscelis spp. & - & - & - & - & - & - & - & - & 1.1 \\
\hline Thysanopoda acutifrons & - & - & 6.8 & - & - & - & - & - & 6.4 \\
\hline T. monacantha & 0.5 & - & - & - & - & - & - & - & - \\
\hline T. pectinata & - & - & 1.2 & - & - & - & - & - & - \\
\hline T. tricuspidata & - & - & 7.1 & - & 0.4 & 6.1 & - & - & - \\
\hline Thysanopoda spp. & 1.6 & 4.9 & - & - & 0.7 & - & - & - & - \\
\hline Euphausiidae unidentified & - & 0.4 & - & 21.5 & 1.6 & - & - & - & - \\
\hline Caridea & 0.6 & - & - & - & - & - & - & - & - \\
\hline Oplophoridae & 16.2 & - & - & - & 3.5 & - & - & - & - \\
\hline Pandalidae & 27.2 & - & - & - & - & - & - & - & - \\
\hline Sergestidae & - & - & - & - & - & 15.4 & - & - & - \\
\hline Decapoda unidentified & - & 2.0 & - & - & 8.2 & 11.6 & - & - & - \\
\hline Ostracoda & & - & 0.2 & - & - & - & - & - & - \\
\hline Crustaceans unidentified & 23.3 & 6.2 & 28.0 & - & 1.0 & - & 17.2 & 0.2 & 36.5 \\
\hline Crustacean eggs & - & - & - & - & - & - & - & 11.8 & 0.1 \\
\hline Ctenophora & - & - & - & - & - & - & - & - & 0.5 \\
\hline Chaetognatha & 0.3 & 14.8 & - & - & 2.7 & - & 0.7 & 4.9 & 1.2 \\
\hline Nematoda & - & - & - & - & $<0.1$ & - & - & - & - \\
\hline Polychaeta & 12.9 & - & - & - & 0.3 & - & 3.5 & - & - \\
\hline Thecosomata & - & 6.5 & - & - & 0.8 & - & 2.5 & 0.2 & - \\
\hline Atlanta spp. & - & 3.9 & - & - & - & - & - & - & - \\
\hline Bivalvia larvae & 0.5 & 1.9 & - & - & - & - & - & - & - \\
\hline Teuthida & 1.9 & 1.3 & - & - & 10.7 & - & - & - & - \\
\hline Osteichthyes & 13.8 & 29.1 & 3.5 & 74.6 & 68.8 & 1.6 & - & 6.4 & 4.0 \\
\hline Unidentified food & 0.1 & 4.6 & 3.3 & - & $<0.1$ & 7.8 & 1.2 & - & 8.2 \\
\hline $\begin{array}{l}\text { Number of stomachs } \\
\text { analysed }\end{array}$ & 41 & 75 & 75 & 13 & 75 & 49 & 75 & 46 & 75 \\
\hline
\end{tabular}

diets between the two broadest clusters; oplophorids and sergestids/pandalids, and a $\sim 60-70$ similarity between the two species with most similar diets. This suggests low levels of competition and likely high resource portioning between pelagic decapod species allowing very diverse decapod community to co-exist [Pakhomov et al., 1992]. Similar pattern of high diversity and low dietary overlap has also been observed for migrating myctophid community in the central NPSG, while myctophids at temperate latitudes have generally exhibited significantly higher dietary overlap [Clarke, 1980].

\section{Potential sources of error}

One the main caveats of the current study could be related to the fact that our stomach content data may not necessarily be representative of predator-prey relationships. There are three main sources of error inherent to using stomach content data to estimate natural diets: secondary feeding, feeding in the cod end, and variable rates of digestion for different prey items. Secondary feeding occurs when a predator consumes prey which in turn has prey in its stomach. Thus, the 
Table 4. Upper and lower boundaries of estimates of the feeding occurrence at depth, expressed as a percentage of feeding during the day. Only for species which were caught in both SSL and DSL.

Таблица 4. Верхний и нижний пределы оценок доли особей, питающихся в глубоких слоях воды в течение дня (в процентах от числа питающихся особей в течение дня). Вычислено только для тех видов, которые пойманы как в SSL (верхний звукорассеивающий слой), так и в DSL (нижний звукорассеивающий слой).

\begin{tabular}{|l|c|c|}
\hline \multicolumn{1}{|c|}{ Species } & $\begin{array}{c}\text { Upper boundary } \\
(\mathbf{\%})\end{array}$ & $\begin{array}{c}\text { Lower boundary } \\
(\mathbf{\%})\end{array}$ \\
\hline Janicella spinicauda & 69.6 & 4.2 \\
\hline Neosergestes orientalis & 42.1 & 24.3 \\
\hline Oplophorus gracilirostris & 48.1 & 8.3 \\
\hline Sergia gardineri & 44.8 & 4.8 \\
\hline Sergia scintillans & 36.6 & 8.8 \\
\hline Stylopandalus richardi & 27.0 & 7.6 \\
\hline & & \\
\hline Mean ( \pm 1SD) & $44.7 \pm 14.3$ & $9.5 \pm 7.0$ \\
\hline Global geometric mean & \multicolumn{2}{|c|}{18.5} \\
\hline
\end{tabular}

stomach of the predator could combine not only prey consumed directly but also a "transit" prey. For example, in the eastern North Atlantic copepods of the genus Pleuromamma were very common in stomachs of the decapod Acanthephyra purpurea but appeared to be rare in the shrimp feeding depths [Foxton, Roe, 1974]. It was assumed that Pleuromamma were not consumed directly by $A$. purpurea but rather via stomachs of shrimp's main prey items, chaetognaths, euphausiids and fish. Arguably, the smallest prey found in the stomachs of the largest decapods may likely be a result of the secondary feeding [Foxton, Roe, 1974]. In our study, bivalve larvae in the stomachs of $A$. smith $i$ or Pleuromamma and foraminiferans in the stomachs of $N$. elegans and $O$. gracilirostris could be indicators of the secondary feeding.

Another potential source of error is feeding within the trawl's cod end. In the cod end of a trawl, organisms are packed very tightly together and the decapods may thus ingested prey that they would not normally consume. This was shown for Sergestes similis [Judkins, Fleminger, 1972]. On another hand, there was little evidence that migratory decapods in the subtropical Atlantic consumed any significant amount of prey in the cod end [Foxton, Roe, 1974]. Although it is impossible to determine the extent of the cod end feeding in our study, this potential source of error cannot be entirely discounted.

Finally, variable digestion rates of different prey taxa must be considered, as prey that are digested quickly are likely underestimated in the diet. For example, decapods could be eating significant quantities of gelatinous organisms which would rarely show up in the stomachs due to their fast digestion. Often, we found in the stomachs grasping hooks of chaetognaths while their bodies were seldom observed suggesting underestimation of their role in decapod diets. The same holds true for osteichthyes due to better presentation in the shrimp stomachs their hard to digest parts: scales, jaw bones, fin rays and eye lenses.

\section{Concluding remarks}

The proportion of active vertical flux mediated by decapods in the total (active and passive) carbon flux estimated by Podeswa [2012] in the tropical Pacific gyre had to be reduced by 26,19 and $28 \%$ at $711 \mathrm{~m}$ (mean micronekton daytime depth), $262 \mathrm{~m}$ (mean micronekton nighttime depth) and $173 \mathrm{~m}$ (the base of the euphotic zone) depths, respectively. This was purely due to calculated in this study levels of daytime feeding which accounted on average for $9.7-44.7 \%$ of night time feeding at the surface. While estimates of the feeding at depth are not available for many pelagic mesozooplankton and macrozooplankton, previous studies have shown that some feeding at depth appears to occur for some copepods [Baars, Oostherhuis, 1984], euphausiids [Hu, 1978; Roe, Badcock, 1984] and decapods [Roe, 1984]. Our study thus calls to increase attempts to quantify feeding at daytime depths for all major migratory groups of organisms, for which active flux estimates have been made, to avoid potentially large overestimates of active flux on a global scale [Bianchi et al., 2013; Davison et al., 2013].

A significant, on average $\sim 20 \%$, decapod feeding appears to occur at the daytime depth in tropical gyres. This needs to be taken into account in currently emerging biochemical models aiming to quantify zooplankton and micronekton derived active downward carbon flux [Francois et al., 2002; Bianchi et al., 2013]. The question further arises whether such a pattern holds true for decapods in other regions of the world ocean and for other migratory species of macroplankton and micronekton community. We would argue that daytime feeding, potentially unquantified "cryptic food web" as we term this, may be significant in the open ocean and urgently requires further studies.

ACKNOWLEDGMENTS. This research was supported by the NSERC DG to PEA. We would like to thank research team and crew who helped to collect samples during the October 2004 research cruise of the NOAA research ship Oscar Elton Sette during the Micronekton Intercalibration Experiment in the Pacific Ocean. We are grateful to Brian Hunt, Svenja Kruse, Roger Francois, Kang Wang, Brock Ramshaw and Désirée Tommasi for their helpful advice, feedback, overall great assistance throughout this project.

\section{References}

Al-Mutairi H., Landry M.R. 2001. Active export of carbon and nitrogen at Station ALOHA by diel migrant zooplankton // Deep Sea Research II. Vol.48. P.2083-2103.

Baars M., Oostherhuis S. 1984. Diurnal feeding rhythms in North Sea copepods measured by gut fluorescence, digestive enzyme activity and grazing on labelled food // Netherlands Journal of Sea Research. Vol.18. P.97-119.

Bianchi D., Stock C., Galbraith E.D., Sarmiento J.L. 2013. Diel vertical migration: Ecological controls and impacts on the biological pump in a one-dimensional ocean model // Global Biochemical Cycles. Vol.27. P.478-491.

Le Borgne R., Rodier M. 1997. Net zooplankton and the biological pump: a comparison between the oligotrophic and mesotrophic equatorial Pacific // Deep Sea Research II. Vol.44. P.2003-2023.

Brodeur R., Yamamura O. 2005. Micronekton of the North Pacific // PICES Scientific Report. Vol.30. P.1-116. 
Chace F.A.J. 1986. The caridean shrimps (Crustacea: Decapoda) of the Albatross Philippine Expedition, 1907-1910, Part 4: Families Oplophoridae and Nematocarcinidae // Smithsonian Contributions to Zoology. No.432. P.1-82.

Clarke K., Warwick R. 2001. Change in Marine Communities: an Appraoch to StatisticalAnalysis and Interpretation. 2nd ed. PRIMER-E Manual. Plymouth.

Clarke T.A. 1980. Diets of fourteen species of vertically migrating mesopelagic fishes in Hawaiian waters // Fishery Bulletin. Vol.78. P.619-640.

Dam H.G., Roman M.R., Youngbluth M.J. 1995. Downward export of respiratory carbon and dissolved inorganic nitrogen by diel-migrant mesozooplankton at the JGOFS Bermuda timeseries station // Deep Sea Research I. Vol.42. P.1187-1197.

Davison P.C., Checkley D.M., Koslow J.A., Barlow J. 2013. Carbon export mediated by mesopelagic fishes in the northeast Pacific Ocean // Progress in Oceanography. Vol.116. P.14-30.

Donaldson H.A. 1975. Vertical distribution and feeding of sergestid shrimps (Decapoda: Natantia) collected near Bermuda // Marine Biology. Vol.31. P.37-50.

Fasham M., Foxton P. 1979. Zonal distribution of pelagicd decapods (Crustacea) in the eastern North Atlantic and its relation to the physical oceanography // Journal of Experimental Marine Biology and Ecology. Vol.37. P.225-253.

Flock M.E., Hopkins T.L. 1992. Species composition, vertical distribution, and food habits of the sergestid shrimp assemblage in the eastern Gulf of Mexico // Journal of Crustacean Biology. Vol.12. P.210-223.

Foxton P. 1970a. The vertical distribution of pelagic decapods (Crustacea: Natantia) collected on the SOND cruise 1965. I. The Caridea // Journal of the Marine Biological Association of the UK. Vol.50. P.939-960.

Foxton P. 1970b. The vertical distribution of pelagic decapods (Crustacea: Natantia) collected on the SOND cruise 1965. II. The Penaeidea and general discussion // Journal of the Marine Biological Association of the UK. Vol.50. P.961-1000.

Foxton P., Roe S. 1974. Observations on the nocturnal feeding of some mesopelagic decapod crustacean // Marine Biology. Vol.28. P.37-49.

Francois R., Honjo S., Kirshfield R., Manganini S. 2002. Factors controlling the flux of organic carbon to the bathypelagic zone of the ocean // Global Biogeochemical Cycles. Vol.16. P.1-20.

Hayward T.L. 1980. Spatial and temporal feeding patterns of copepods from the North PacificCentral gyre // Marine Biology. Vol.58. P.295-309.

Hidaka K., Kawaguchi K., Murakami M., Takahashi M. 2001. Downward transport of organic carbon by diel migratory micronekton in the western equatorial Pacific: its quantitative and qualitative importance // Deep Sea Research I. Vol.48. P.1923-1939.

Holton A. 1969. Feeding behaviour of a vertically migrating lanternfish // Pacific Science. Vol.23. No.3. P.325-331.

Hopkins T.L., Flock M.E., Gartner J.V., Torres J.J. 1994. Structure and trophic ecology of a low latitude midwater decapod and mysid assemblage // Marine Ecology Progress Series. Vol.109. P.143-156.

Hopkins T.L., Gartner J.V., Flock M.E. 1989. The caridean shrimp (Decapoda: Natantia) assemblage in the mesopelagic zone of the eastern Gulf of Mexico // Bulletin of Marine Science. Vol.45. P.1-14.

Hopkins T.L., Sutton T.T. 1998. Midwater fishes and shrimps as competitors and resource partitioning in low latitude oligotrophic ecosystems // Marine Ecology Progress Series. Vol.164. P.37-45.

Hu V.J.H. 1978. Relationships between vertical migration and diet in four species of euphausiids // Limnology and Oceanography. Vol.23. P.296-306.

Hull P.M., Osborn K.J., Norris R.D., Robison B.H. 2011. Seasonality and depth distribution of a mesopelagic foraminifer, Hastigerinella digitata, in Monterey Bay, California // Limnology and Oceanography. Vol.56. P.562-576.

Hunt J.L., Jr., Kato H., McKinnel S.M. 2000. Predation by marine birds and mammals in the Subarctic North Pacific Ocean // PICES Scientific Report. Vol.14. P.1-165.
Hureau J.C. 1969. Biologie comparée de quelques poissons antarctiques (Nototheniidae) // Bulletin de l'Institut Oceanographique. Vol.68. P.1-44.

Judkins D.C., Fleminger A. 1972. Comparison of foregut contents of Sergestes similis obtained from net collections and albacore stomachs // Fishery Bulletin. Vol.70. P.217-223.

Kaeriyama M., Nakamura M., Edpalina R., Bower J.R., Yamaguchi H., Walker R.V., Myers K.W. 2004. Change in feeding ecology and trophic dynamics of Pacific salmon (Oncorhynchus spp.) in the central Gulf of Alaska in relation to climate events // Fisheries Oceanography. Vol.13. No.3. P.197-207.

Karl D.M. 1999. A sea of change: Biogeochemical variability in the North Pacific Subtropical Gyre // Ecosystems. Vol.2. P.181-214.

Longhurst A.R. 1991. Role of the marine biosphere in the global carbon cycle // Limnology and Oceanography. Vol.36. P.15071526.

Longhurst A.R., Bedo A.W., Harrison W.G., Head E.J., Horne E.P., Irwin B., Morales C. 1989. NFLUX: a test of vertical nitrogen flux by diel migrant biota // Deep Sea Research. Vol.36. P.1705-1719.

Longhurst A.R., Bedo W.G., Harrison E.J.H., Sameoto D.D. 1990. Vertical flux of respiratory carbon by oceanic diel migratory biota // Deep Sea Research I. Vol.37. P.685-694.

Longhurst A., Williams R. 1992. Carbon flux by seasonal vertical migrant copepods is a small number // Journal of Plankton Research. Vol.14. P.1495-1509.

Mauchline J. 1985. Growth and production of Euphausiacea (Crustacea) in the Rockall Trough // Marine Biology. Vol.90. P.19-26.

Maynard S.D., Riggs F.V., Walters J.F. 1975. Mesopelagic micronekton in Hawaiian waters: faunal composition, standing stock, and diel vertical migration // Fishery Bulletin. Vol.73. P.726-736.

Nemoto T. 1968. Chlorophyll pigments in the stomach of euphausiids // Journal of the Oceanographical Society of Japan. Vol.24. P.253-260.

Pakhomov E.A., Melnikov V.V., Koltsov O.V. 1992. Pelagic shrimps (Crustacea, Decapoda) of the backscattering layers in the equatorial Indian Ocean // Arthropoda Selecta. Vol.1. No.1. P.87-95.

Pakhomov E.A.,Yamamura O. (eds.). 2010. Report of the Advisory Panel on Micronekton Sampling Inter-calibration Experiment // PICES Scientific Report. Vol.38. P.1-108.

Podeswa Y. 2012. Active carbon transport and feeding ecology of pelagic decapods in the North Pacific Subtropical Gyre. MSc Thesis. University of British Columbia. Canada. 129 p.

Roe H.S.J. 1984. The diel migrations and distributions within a mesopelagic community in the north east Atlantic. 2. Vertical migrations and feeding of mysids and decapod crustacea // Progress in Oceanography. Vol.13. P.269-318.

Roe H.S.J., Badcock J. 1984. The diel migrations and distributions within a mesopelagic community in the north east Atlantic. 6. Vertical migrations and feeding of fish // Progress in Oceanography. Vol.13. P.389-424.

Shorygin A.A. 1952. [Pitanie i pishchevye vzaimootnoshenija ryb Kaspiyskogo morya]. Moscow: Pishchepromizdat. 268 p. [in Russian].

Steinberg D., Cope J., Wilson S., Kobari T. 2008. A comparison of mesopelagic mesozooplankton community structure in the subtropical and subarctic North Pacific Ocean // Deep Sea Research II. Vol.55. P.1615-1635.

Steinberg D.K., Carlson C.A., Bates N.R., Goldthwait S.A., Madin L.P., Michaels A.F. 2000. Zooplankton vertical migration and the active transport of dissolved organic and inorganic carbon in the Sargasso Sea // Deep Sea Research I. Vol.47. P.137-158.

Steinberg D.K., Goldthwait S.A, Hansell D.A. 2002. Zooplankton vertical migration and the active transport of dissolved organic and inorganic nitrogen in the Sargasso Sea // Deep Sea Research I. Vol.49. P.1445-1461.

Stuart V., Pillar S.C. 1990. Diel grazing patterns of all ontogenetic stages of Euphausia lucens and in situ predation rates on copepods in the southern Benguela upwelling region // Marine Ecology Progress Series. Vol.64. P.227-241.

Walters J.F. 1976. Ecology of Hawaiian sergestid shrimps (Penaeidae: Sergestidae) // Fishery Bulletin. Vol.74. No.4. P.799-836.

Responsible editor V.A. Spiridonov 